\title{
Subnanometer Thick Carbon-Layer-Encapsulated Silver Nanoparticles Selectively Neutralizing Human Cancer Cells and Pathogens through Controlled Release of $\mathrm{Ag}^{+}$Ions
}

Md. Akherul Islam ${ }^{1 a}$, Kamal Prasad Sapkota ${ }^{2 a}$, Thoufiqul Alam Riaz ${ }^{3}$, Md. Amjad Hossain ${ }^{4}$, Md. Abu Hanif ${ }^{1}$, Jeasmin Akter ${ }^{2}$, Md. Monir Hossain ${ }^{1,5}$, Se Gyu Jang ${ }^{5}$, Han-Jung Chae ${ }^{6}$, Jae Ryang Hahn 1,2,7*

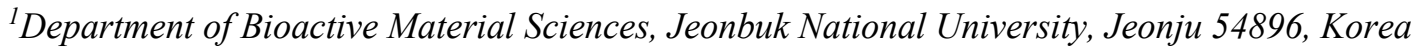

${ }^{2}$ Department of Chemistry and Research Institute of Physics and Chemistry, Jeonbuk National University, Jeonju 54896, Korea

${ }^{3}$ Department of Pharmacology, Jeonbuk National University Medical School, Jeonju 54896, Korea

${ }^{4}$ College of Veterinary Medicine, Biosafety Research Institute, Jeonbuk National University, Iksan 54596, Korea

${ }^{5}$ Functional Composite Materials Research Center, Institute of Advanced Composites Materials, Korea Institute of Science and Technology, Wanju, Jeonbuk 55324, Korea

${ }^{6}$ School of Pharmacy, Jeonbuk National University, Jeonju 54896, Korea

${ }^{7}$ Textile Engineering, Chemistry and Science, North Carolina State University 2401 Research Dr. Raleigh, NC 27695-8301, USA

${ }^{a}$ M.A.I. and K.P.S are equally contributed to the present work.

*Corresponding author (JRH): jhahn@ncsu.edu 


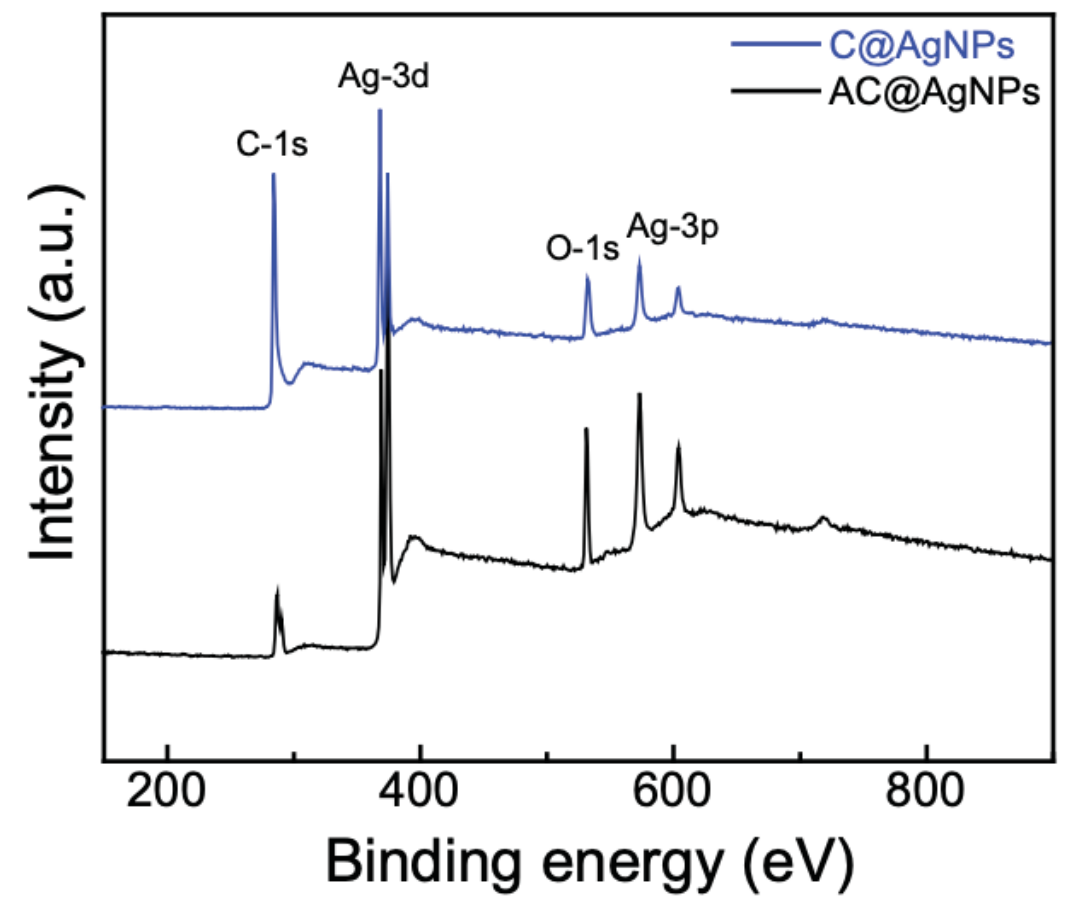

Figure S1. XPS survey spectra of the C@AgNPs and AC@AgNPs.
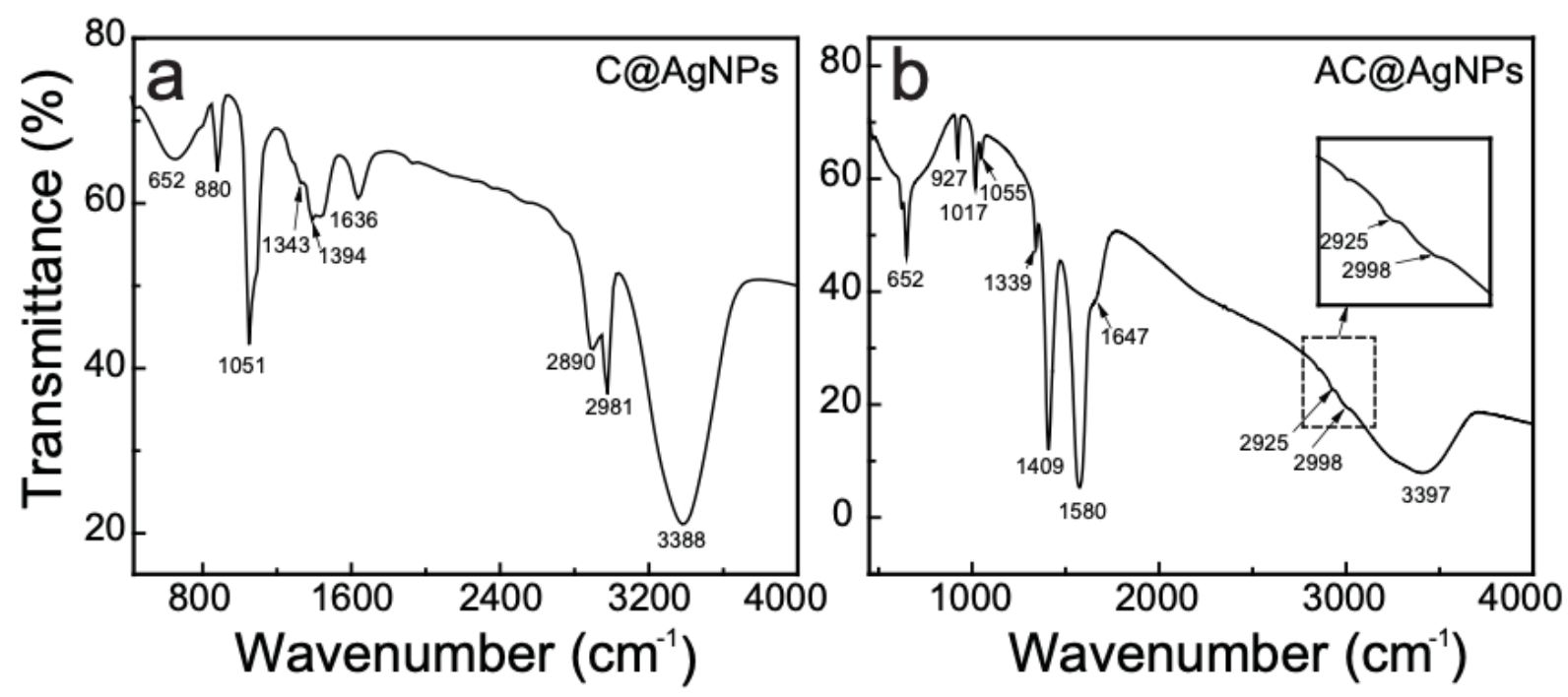

Figure S2. FT-IR spectra of (a) C@AgNPs and (b) AC@AgNPs. 

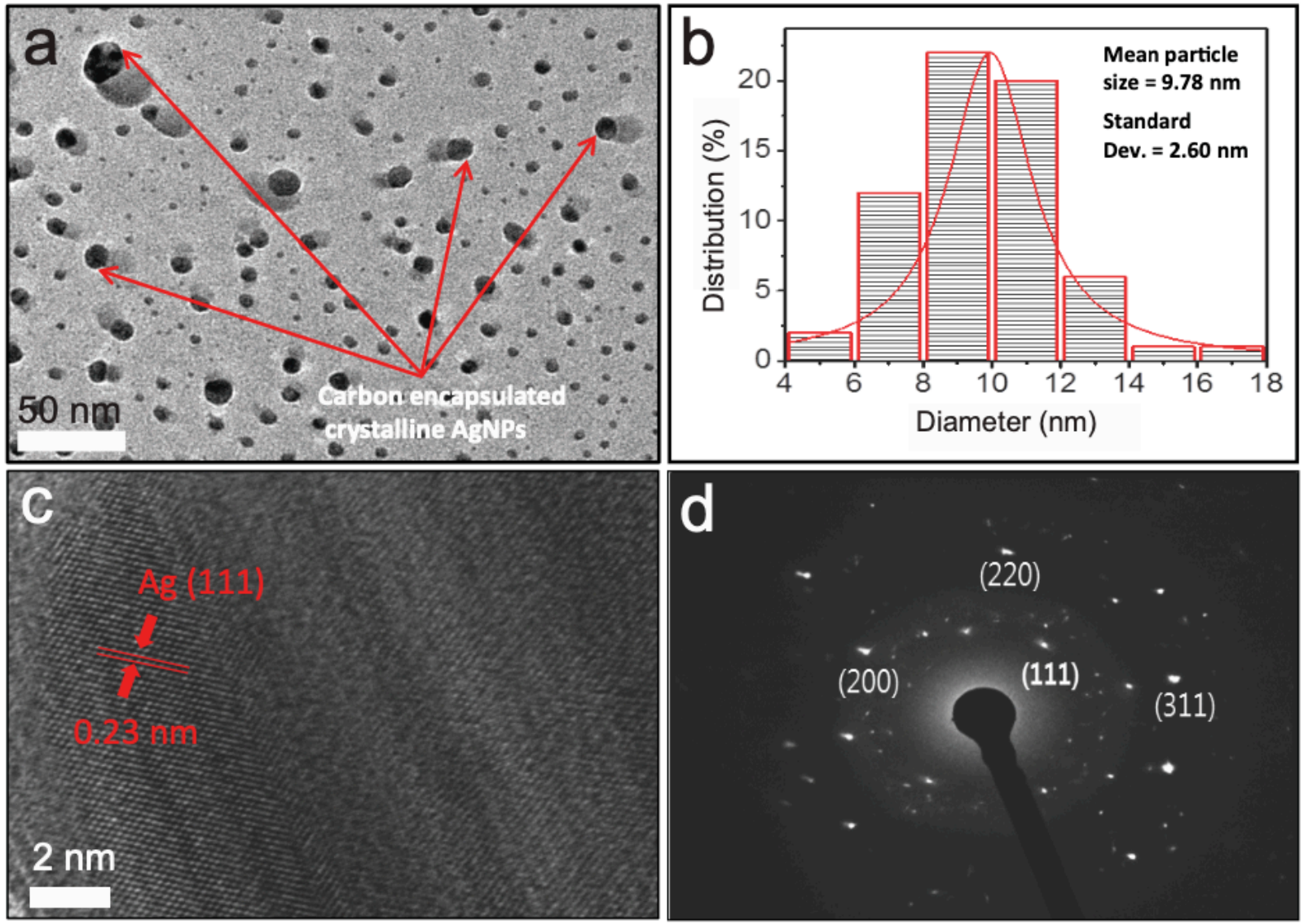

Figure S3. (a) Low-resolution image of the dispersed C@AgNPs. (b) Histogram of the particle diameter distribution. (c) High-resolution image showing the crystalline structure of core AgNPs. (d) Selected-area electron diffraction (SAED) pattern.
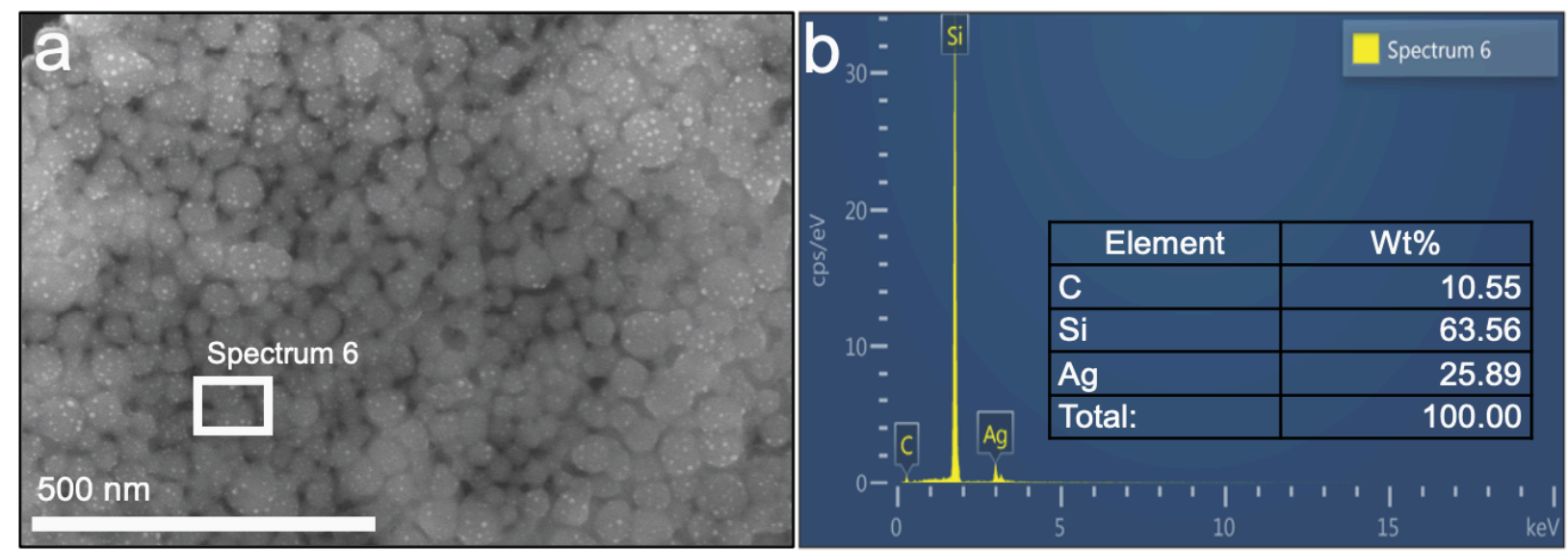

Figure S4. (a) FE-SEM image and (b) EDS spectrum of the C@AgNPs. 


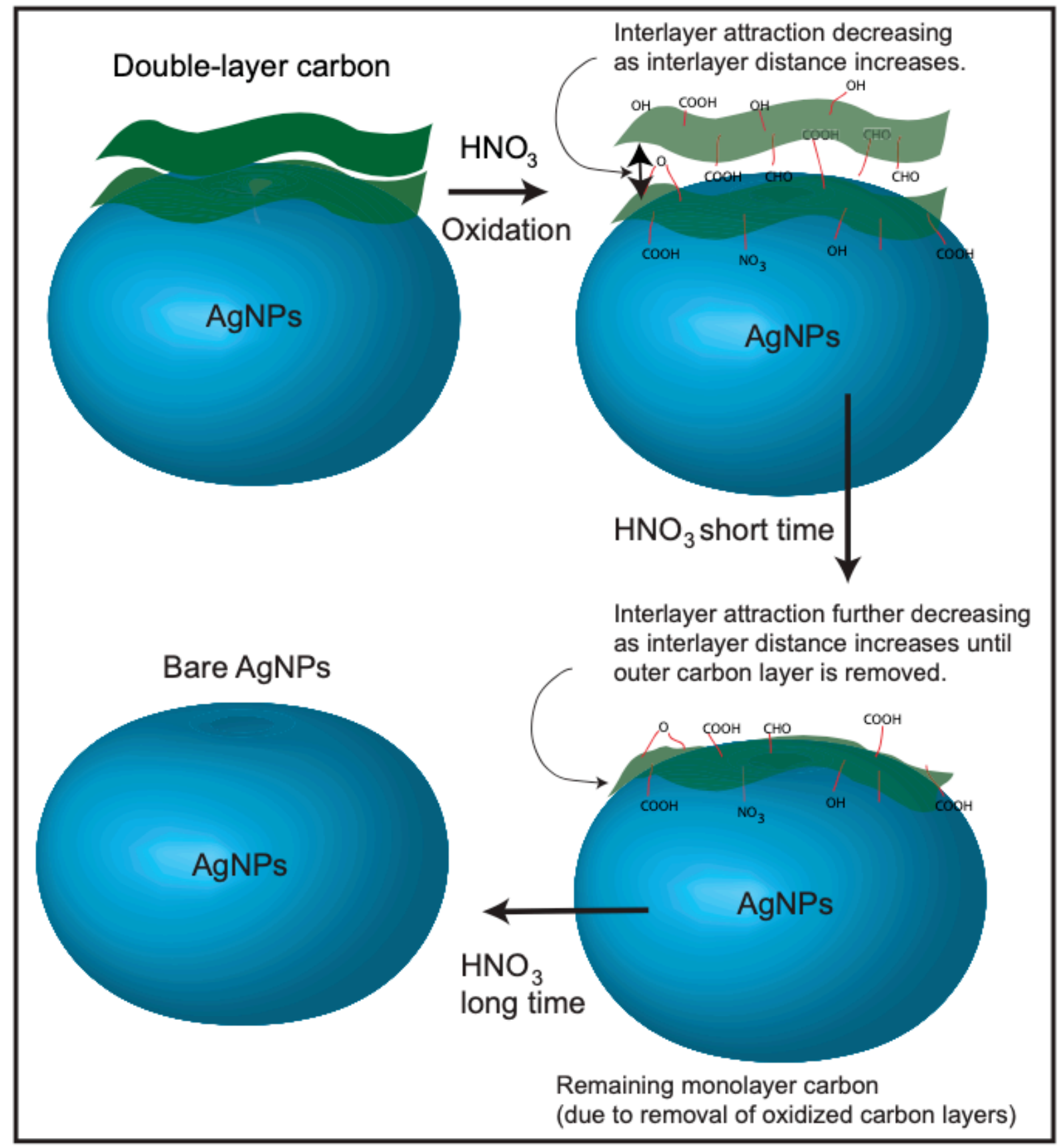

Figure S5. Proposed mechanism for the exfoliation of the outer carbon layer from C@AgNPs. 


\section{The oxidation process of double-laver carbon}

In the present work, we used diluted nitric acid that slowly reduced the carbon layer. It is possible that the $-\mathrm{OH}$ group of the carbon source (ethanol) is first oxidized into aldehyde and finally into acid group by nitric acid (oxidation of ethanol by $\mathrm{HNO}_{3}$ ). Such a reaction depletes the outer carbon layer. In addition, when concentrated nitric acid was used (instead of dilute), the carbon coated AgNPs dissolved completely resulting in a solution. Our observations are also supported by references; they used nitric acid to remove the encapsulated carbon from materials surface [R1-R3].

It is well known that a highly oriented carbon structure like HOPG (highly oriented pyrolytic graphite) is very inert. However, the presented double-layer carbon differs from the top two layers of HOPG. HOPG is so inert that it can be oxidized at very high temperatures $\left(\sim 875^{\circ} \mathrm{C}\right)$ [R4]. In other words, the $s p^{2}$ carbon is very inert. On the other hand, when HOPG is defected by radiation or ion beam, the reactivity increases significantly [R5-R8]. Defects in HOPG may include point defects (vacancies and interstitials), line defects (steps), and chemical defect (chemically functionalized carbons as discussed above). For example, carbons around a point defect can be oxidized even at lower temperatures $\left(\sim 450^{\circ} \mathrm{C}\right)$ and the activation barrier is lowered [R5-R7].

The presented double-layer carbon was not prepared in the same way as HOPG. Thus, we think that there are many defects in the double-layer carbon. The chemical defects (functionalized carbon) can be seen in XPS spectra. Point defects can be observed by the local probe techniques like scanning tunneling microscope), but it was very difficult because of difficult handling of the nanoparticles. It is also notable that the double-layer carbon can be deformed by spherical-shaped Ag nanoparticles, so the reactivity may increase due to the disruption of the carbon bonds. Additionally, the electron transfer between $\mathrm{Ag}$ and the carbon layer is likely to cause the carbon to become partially charged. In view of these findings and factors, we concluded that the presented double-layer carbon may contain defects, and the defected carbons can be oxidized by nitric acid, and ultimately becomes monolayer carbon.

It should also be pointed out that further oxidation of monolayer carbon (AC@AgNPs) by nitric acid led to the formation of bare AgNPs as shown in Figure S7. This may also be due to the presence of defects in the carbon monolayer and complete peeling off the monolayer. 

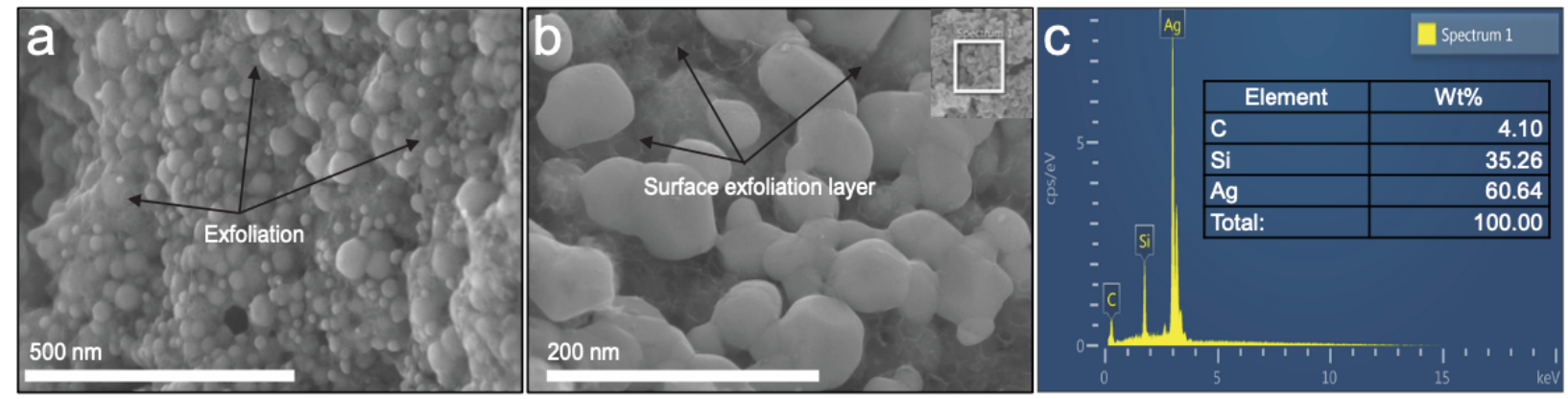

Figure S6. (a) and (b) FE-SEM images of AC@AgNPs. (c) EDS spectrum corresponding to the rectangular area in the inset of image (b).
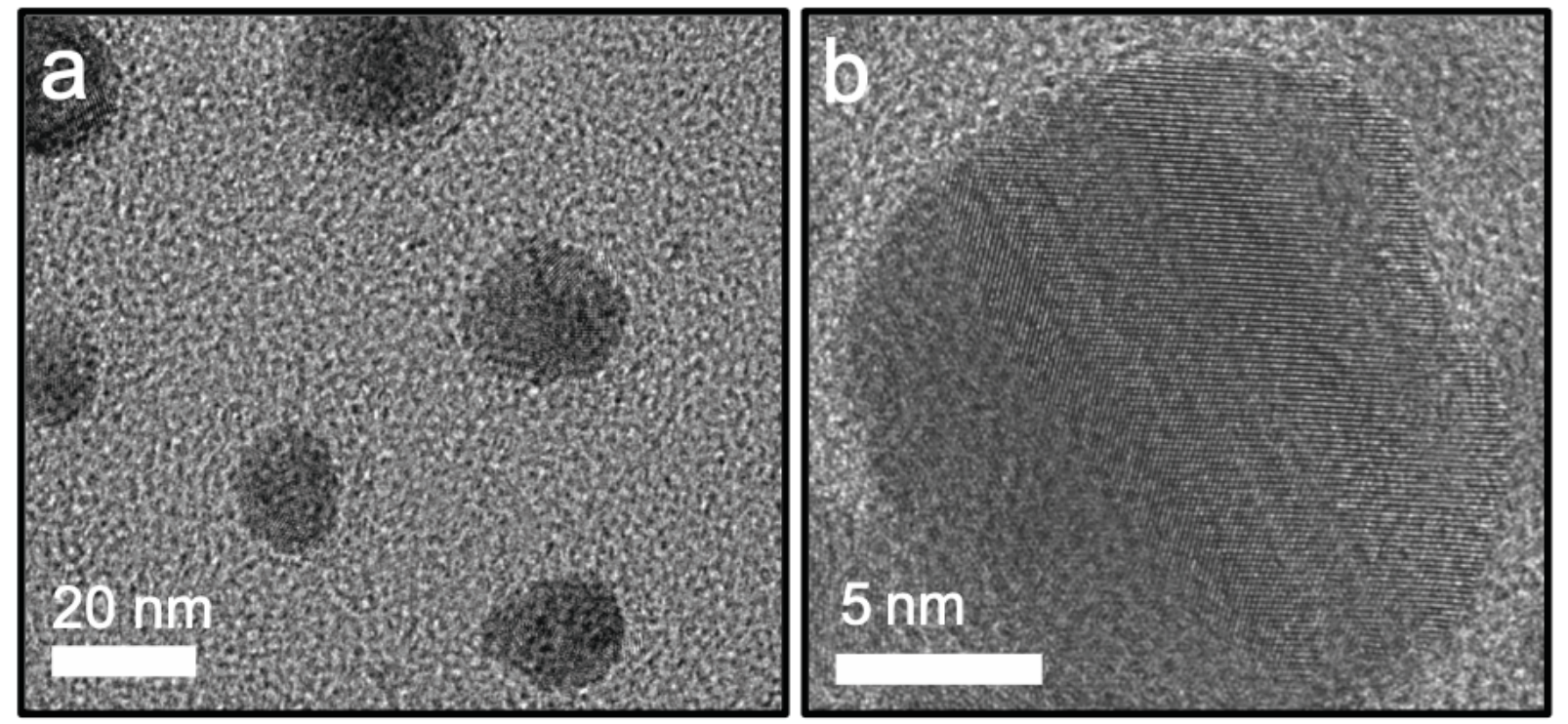

Figure S7. (a) and (b) HR-TEM images of the bare AgNPs.

Table S1. Specific surface area $\left(S_{\mathrm{BET}}\right)$, total pore volume $\left(V_{\text {pore }}\right)$, and average pore diameter $\left(D_{\text {pore }}\right)$ of the AC@AgNPs and C@AgNPs.

\begin{tabular}{cccc}
\hline \hline Sample & $\begin{array}{c}\text { Specific surface area } \\
\left(S_{\mathrm{BET}}, \mathrm{m}^{2} \mathrm{~g}^{-1}\right)\end{array}$ & $\begin{array}{c}\text { Total pore volume } \\
\left(V_{\text {pore }}, \mathrm{cm}^{3} \mathrm{~g}^{-1}\right)\end{array}$ & $\begin{array}{c}\text { Average pore diameter } \\
\left(D_{\text {pore }}, \mathrm{nm}\right)\end{array}$ \\
\hline AC@AgNPs & 18.22 & 0.033 & 7.45 \\
$\mathrm{C} @$ AgNPs & 9.50 & 0.012 & 20.23 \\
\hline \hline
\end{tabular}




\section{pH-dependent zeta potential measurements}

In order to understand the surface charge characteristics of C@AgNPs and AC@AgNPs, we performed $\mathrm{pH}$ dependent Zeta Potential measurements (Nano ZS90, Malvern Instruments, UK). The isoelectric point was 4.25 and 5.0 for C@AgNPs and AC@AgNPs, respectively (Figure S8). The zeta potential values of +20.1 to $-41.2 \mathrm{mV}$ and +30.5 to $-65 \mathrm{mV}$ for AC@AgNPs and C@AgNPs, respectively, within a wide $\mathrm{pH}$ range, suggested higher surface charge in both samples. High value of zeta potential represents higher electrical charge on the surface of the nanoparticles, which causes strong repulsive forces among the particles that prevents agglomeration. We observed higher negative charge zeta potential value of about $-65 \mathrm{mV}$ that was observed for C@AgNPs. This negative value is well within higher $\mathrm{pH}$ range for higher stability compared to the AC@AgNPs value.

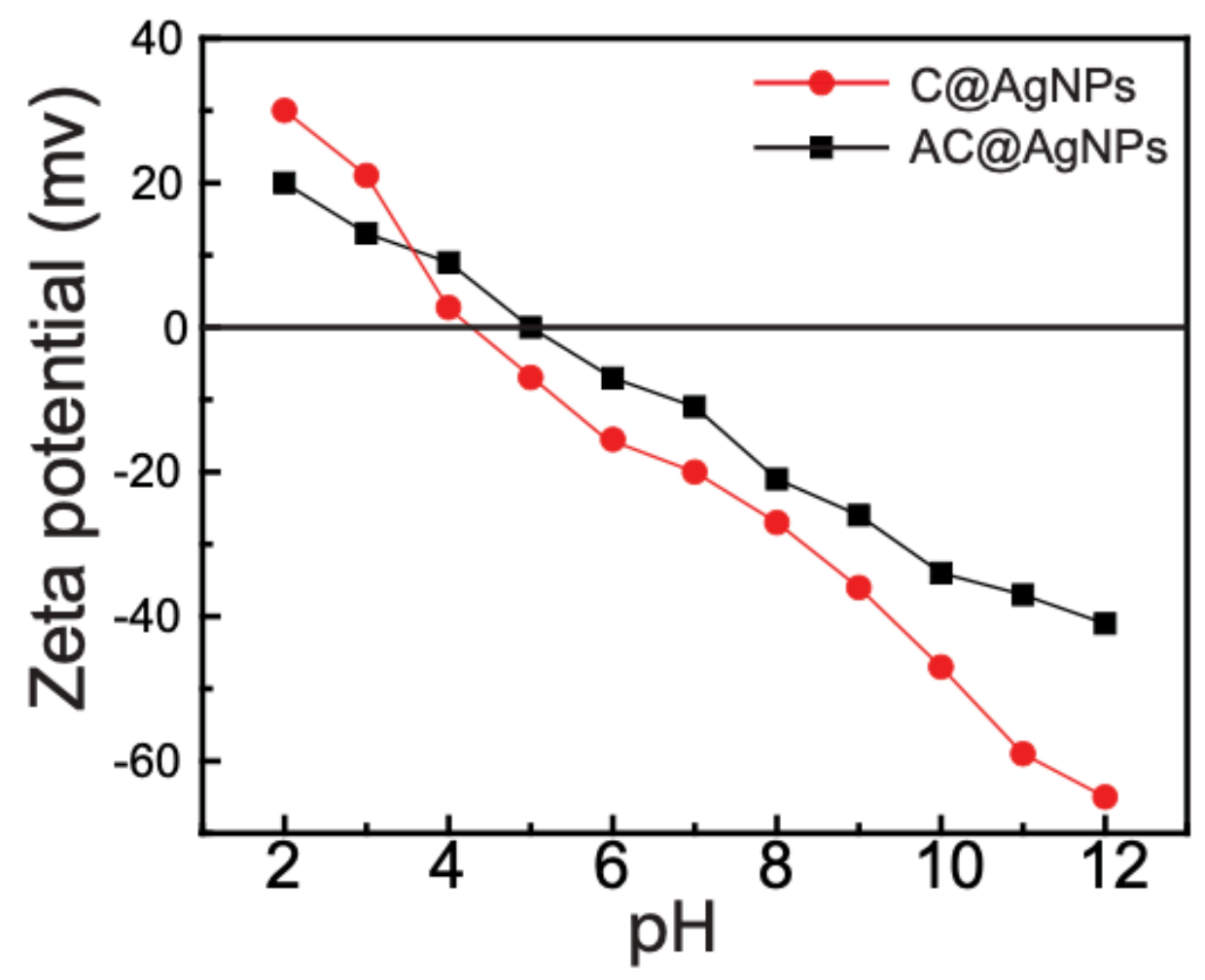

Figure S8. pH dependent surface charge characterization of C@AgNPs and AC@AgNPs. 


\section{$\underline{\text { UV-Vis absorbance measurement as a function of time }}$}

The $\mathrm{Ag}^{+}$ion-release rate of the prepared C@AgNPs, AC@AgNPs, and pristine AgNPs (control) was studied by UV-Vis absorbance measurement as a function of time (at 6, 12, 24, and 48 hours), Figure S9. The results exhibit the highest decrease in absorption maxima for bare AgNPs compared to the C@AgNPs and AC@AgNPs. The higher decrease in absorption maxima indicates the correspondingly higher decrease in nanoparticle concentration due to higher release of $\mathrm{Ag}^{+}$ ions into the solution. The AgNPs coated with a double-layer of carbon makes $\mathrm{Ag}^{+}$dissolution into the solution more difficult because of the obstruction by the carbon walls, thereby reducing the $\mathrm{Ag}^{+}$-ion emanation rate. $\mathrm{The}^{+} \mathrm{Ag}^{+}$ion release was optimum when the carbon layer encapsulating AgNPs was treated with nitric acid, likely because of both the reduction in thickness and the functionalization of the carbon layer to make carbon monolayer AgNPs. Furthermore, $\mathrm{Ag}^{+}$ion release was comparatively higher from the bare AgNPs due to the removal of carbon layer completely. Higher production of $\mathrm{Ag}^{+}$ions means higher toxicity.

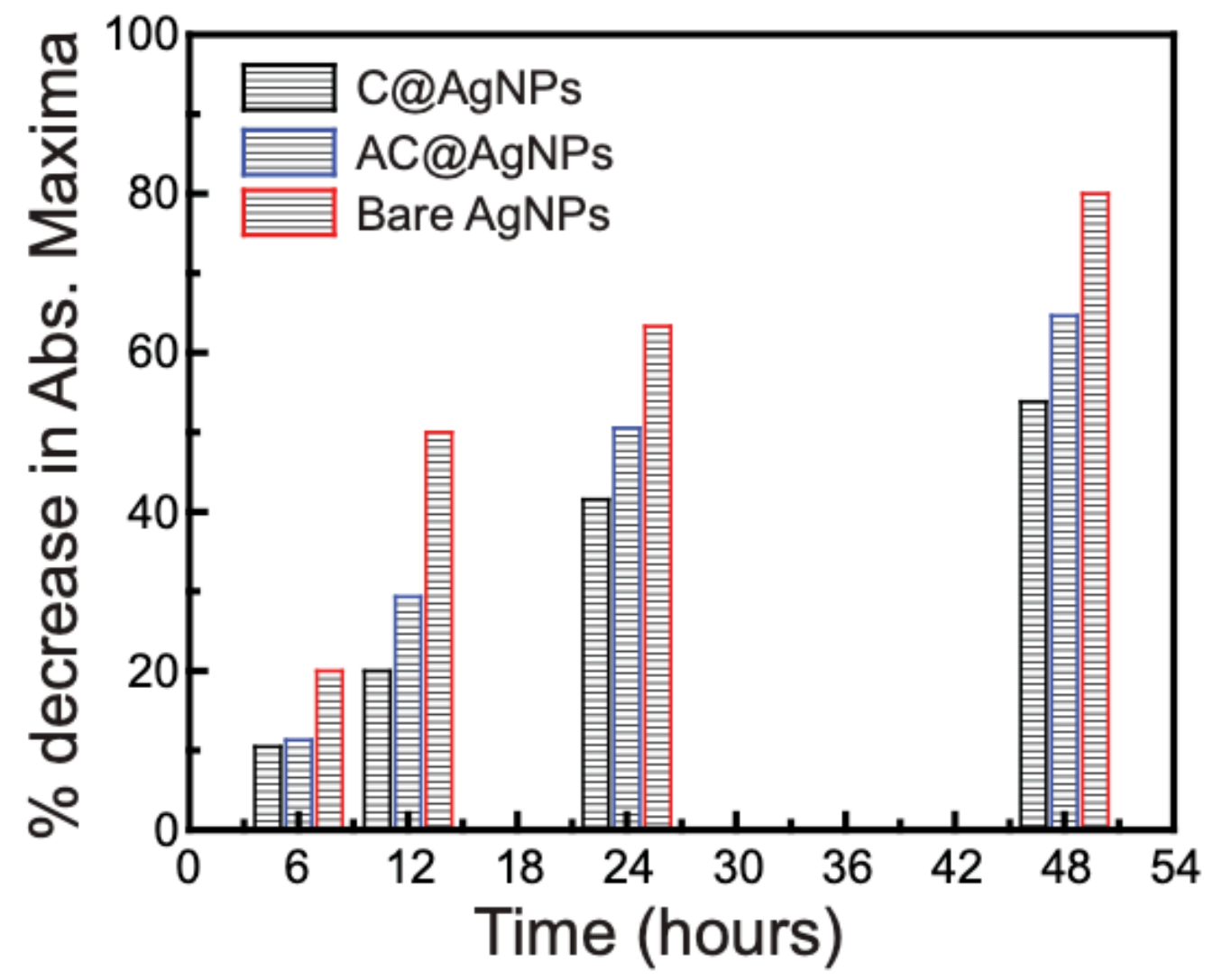

Figure S9. Percent change in absorbance maxima for C@AgNPs, AC@AgNPs, and bare AgNPs due to $\mathrm{Ag}^{+}$ion release. 

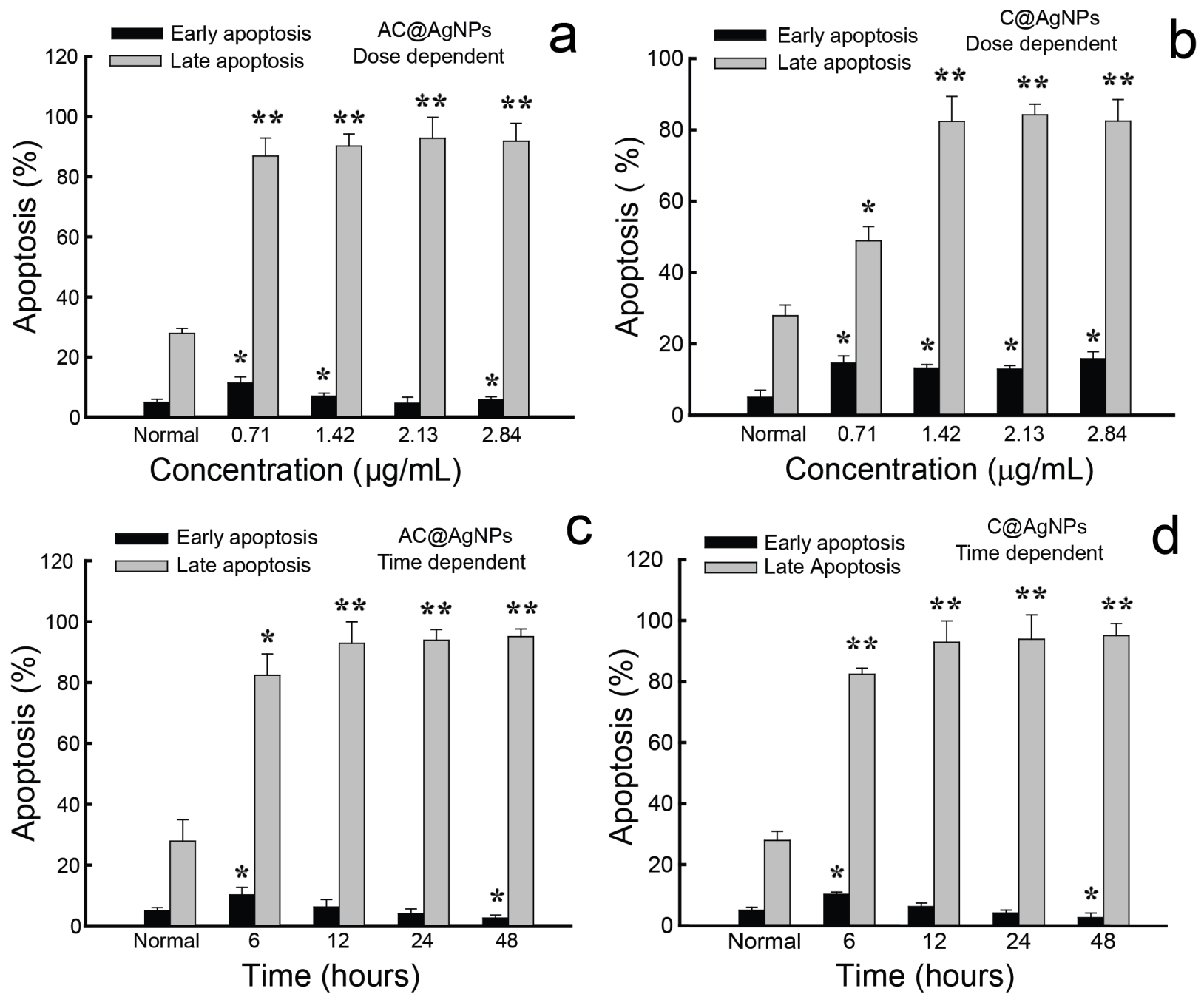

Figure S10. Dose- and time-dependent efficiency of AC@AgNPs and C@AgNPs on the late and early apoptosis of K562 cancer cells. Late apoptosis in dose-dependent cases: (a) AC@AgNPs and (b) C@AgNPs, and in time-dependent cases: (c) AC@AgNPs and (d) C@AgNPs. All data are expressed as the average with standard deviation of three independent experiments. Comparisons were made using analysis of variance and two-tailed unpaired Student t-test. The $\mathrm{p}$ values were considered statistically significant between treated and untreated scores. Figures a, b, c, and d represent the statistical analysis of flow cytometry tests using K562 cells ( $\left.{ }^{*} \mathrm{p} \leq 0.05,{ }^{* *} \mathrm{p} \leq 0.01\right)$. 


\section{Flow cytometry tests}

Flow cytometry tests for the bare AgNPs were performed against the K562 cancer cells. We used a lower dose $0.71 \mu \mathrm{g} / \mathrm{mL}$ (Figure S11b), an optimized dose $2.13 \mu \mathrm{g} / \mathrm{mL}$ (Figure S11c), and the cells without treatment (Figure S11a) for 24 hours. The late apoptosis rates were $88.8 \%$ for $0.71 \mu \mathrm{g} / \mathrm{mL}$, and $98.4 \%$ for $2.13 \mu \mathrm{g} / \mathrm{mL}$, respectively. Bare AgNPs loading late apoptosis rate was 107 and 119\% higher than AC@AgNPs and C@AgNPs for $2.13 \mu \mathrm{g} / \mathrm{mL}$.
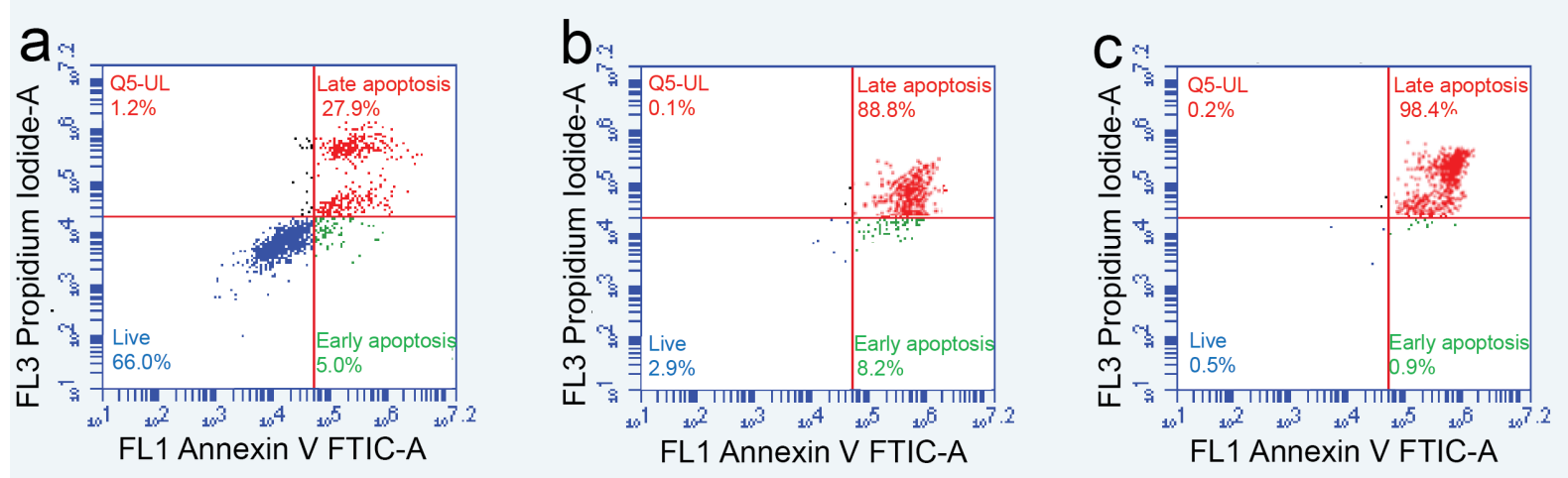

Figure S11. Dose-dependent efficiency of AgNPs on the apoptosis of K562 cancer cells by flow cytometry: (a) cells without treatment, and bare AgNPs with concentrations (b) 0.71, (c) 2.13 $\mu \mathrm{g} / \mathrm{mL}$ against cancer cells. All samples were applied for 24 hours. 


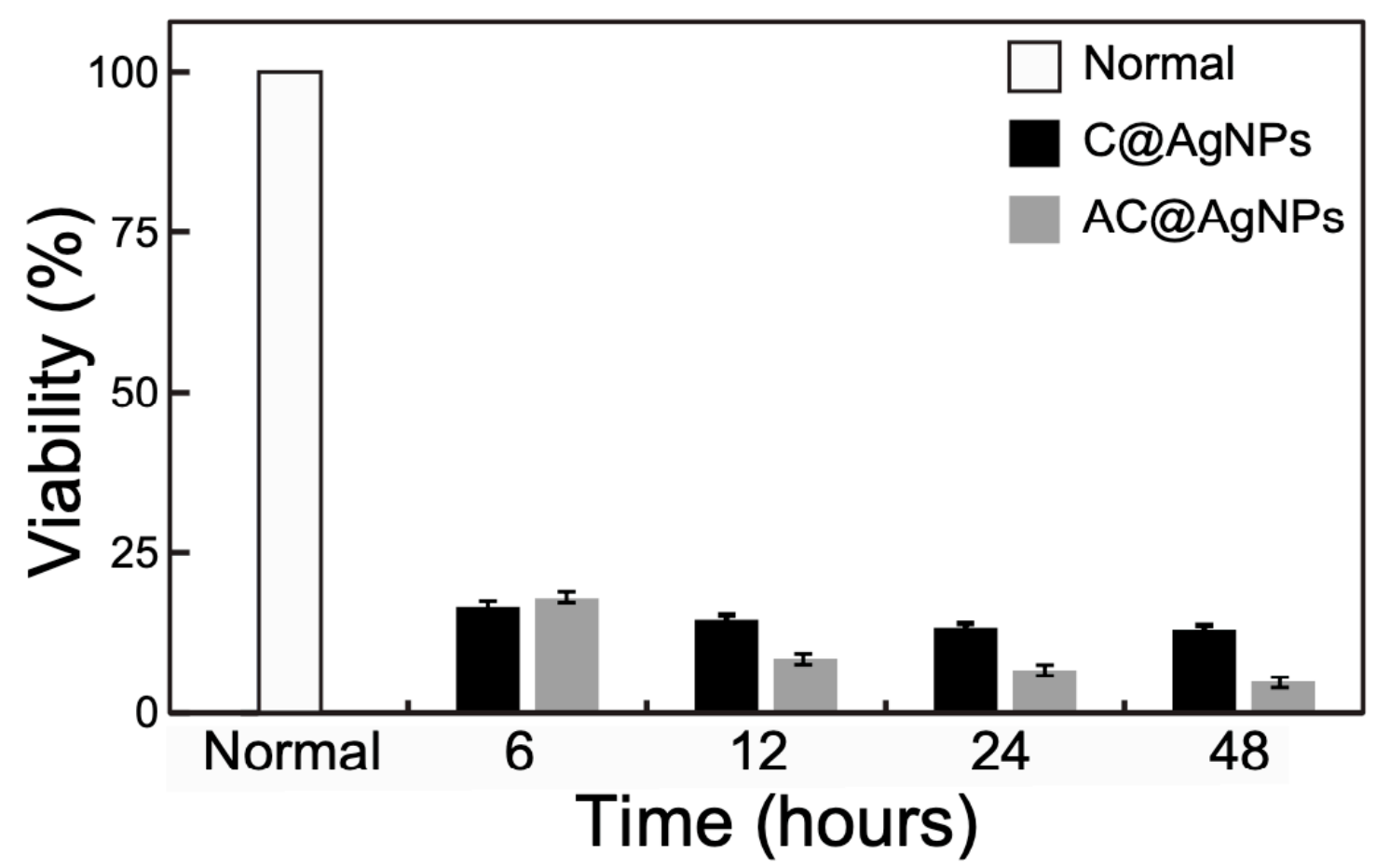

Figure S12. AC@AgNPs and C@AgNPs time-dependent effect on the viability of K562 cancer cells using $2.13 \mu \mathrm{g} / \mathrm{mL}$ of nanoparticles for different time durations $(6,12,24$, and $48 \mathrm{~h})$. Results are displayed as mean $\pm \mathrm{SD}$ of three tests carried out in three replicates. Cells without treatment were used as normal.

Flow cytometry tests were conducted to examine the apoptosis by the prepared samples C@AgNPs, AC@AgNPs, and bare AgNPs against normal cell lines (LO2) and cancer cell lines (Hep3B). The LO2 and Hep3B cells were subjected to the maxumum concentrations $(2.5 \mu \mathrm{g} / \mathrm{mL})$ of samples to evaluate the late and early apoptosis for $24 \mathrm{~h}$. In LO2 cell lines, the late apoptosis were 3.3, 4.9, and 5.5\% (live cells- 91.3, 88.1, and 87.9\%) for C@AgNPs, AC@AgNPs, and AgNPs, respectively, Figure S13 (a-c), whereas the late apoptosis in Hep3B cells were 86.35, 91.9, and 97.8\% (live cells- 4.5, 2.8, 0.8\%) for C@AgNPs, AC@AgNPs, and AgNPs, respectively, Figure S14 (a-c). The results showed the majority of the cells remaining alive for LO2 cells, and almost completely dead for Hep3B cells. LO2 and Hep3B cytometry results are matching with crystal violet results using C@AgNPs, AC@AgNPs, and AgNPs (see Figure 9). These results confirmed that our prepared C@AgNPs, AC@AgNPs, and AgNPs are selective, which act against cancer cells lines. Apoptosis-related protein expression employing caspase-3 and PARP were also evaluated; results show the increased expression of apoptosis-related protein (cleaved caspase-3 and cleaved PARP) against Hep3B cells ( see Figure 10a). In contrast, protein expression was not visible in LO2 normal cell lines (see Figure 10a). The flow cytometry apoptosis results match well with the western blot results. 

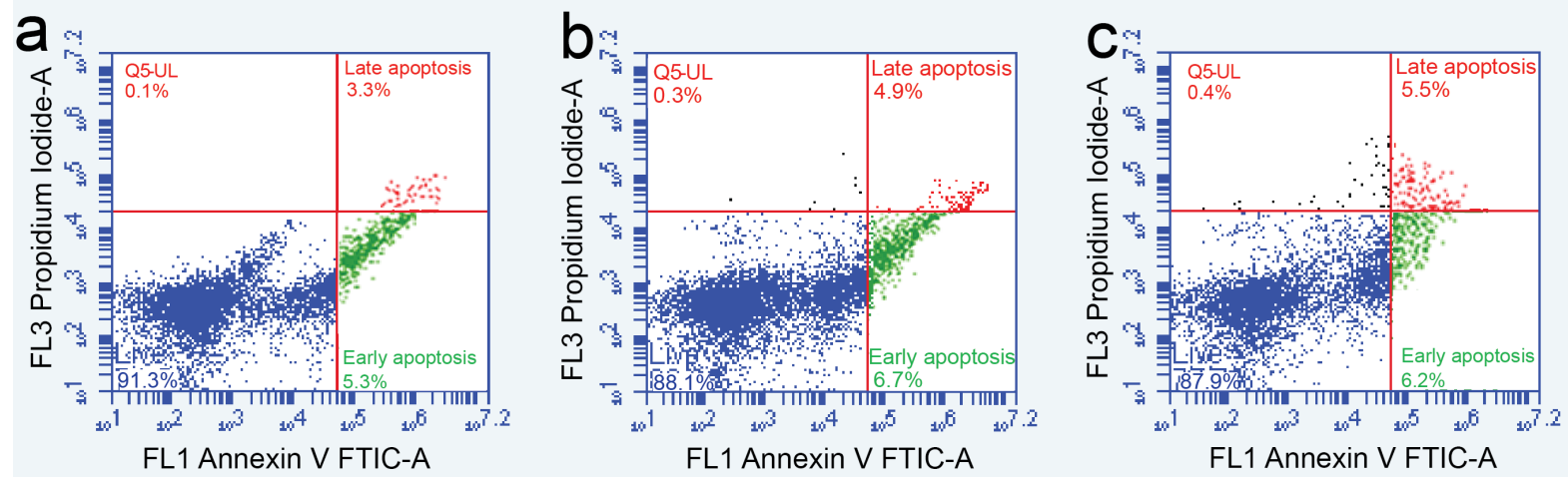

Figure S13. Flow cytometry test of (a) C@AgNPs, (b) AC@AgNPs, and (c) bare AgNPs on the apoptosis of LO2 normal cell lines. All samples were applied at maximum concentration, 2.5 $\mu \mathrm{g} / \mathrm{mL}$ for 24 hours.
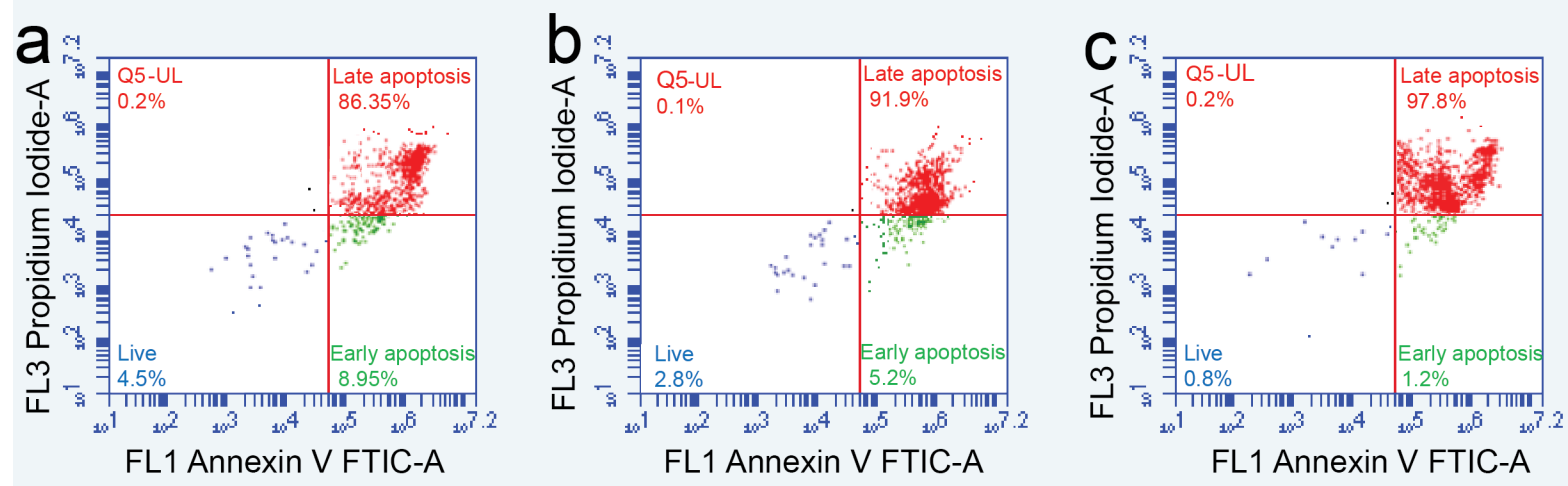

Figure S14. Flow cytometry test of (a) C@AgNPs, (b) AC@AgNPs, and (c) bare AgNPs on the apoptosis of Hep3B cancer cell lines. All samples were applied at maximum concentration, 2.5 $\mu \mathrm{g} / \mathrm{mL}$ for 24 hours. 


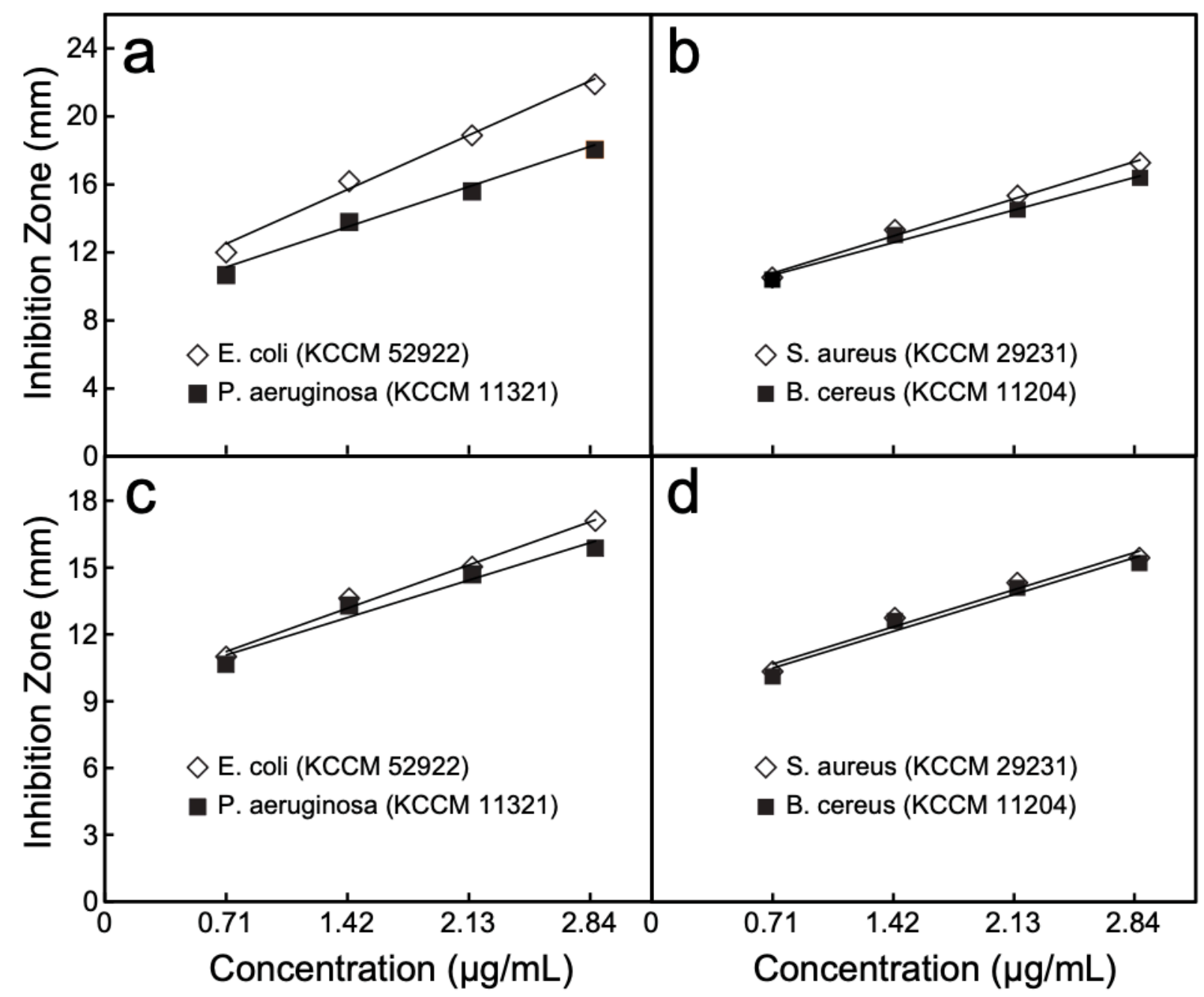

Figure S15. AC@AgNPs and C@AgNPs dose-dependent effective antibacterial performances lead to linear inhibition zones against GN and GP bacteria. (a) AC@AgNPs used against GN bacteria (E. coli and P. aeruginosa) and (b) GP bacteria (S. aureus and B. cereus), (c) C@AgNPs used against GN bacteria (E. coli and P. aeruginosa) and (d) GP bacteria (S. aureus and B. cereus) at various concentrations. 


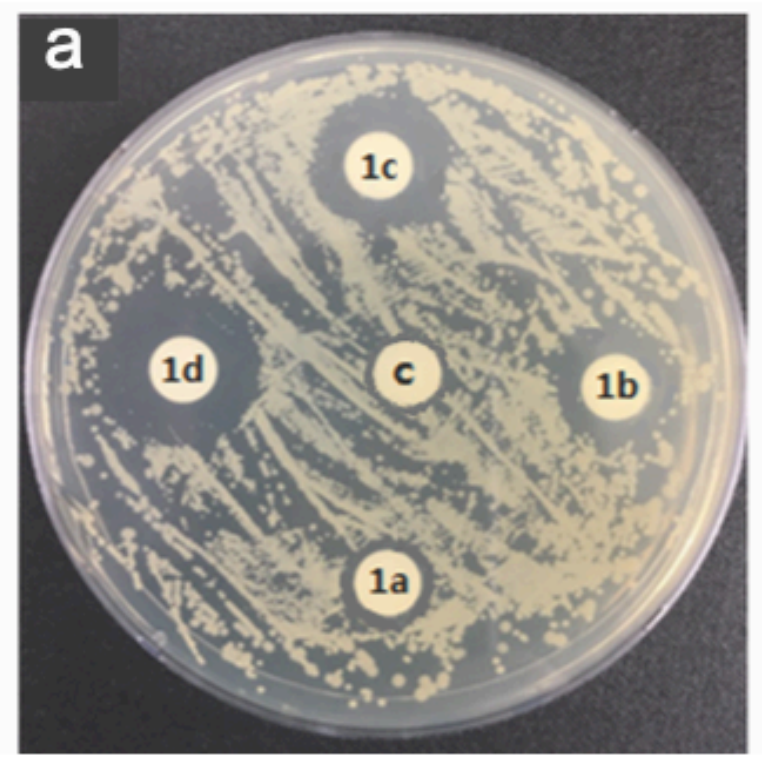

Escherichia coli KCCM 52922

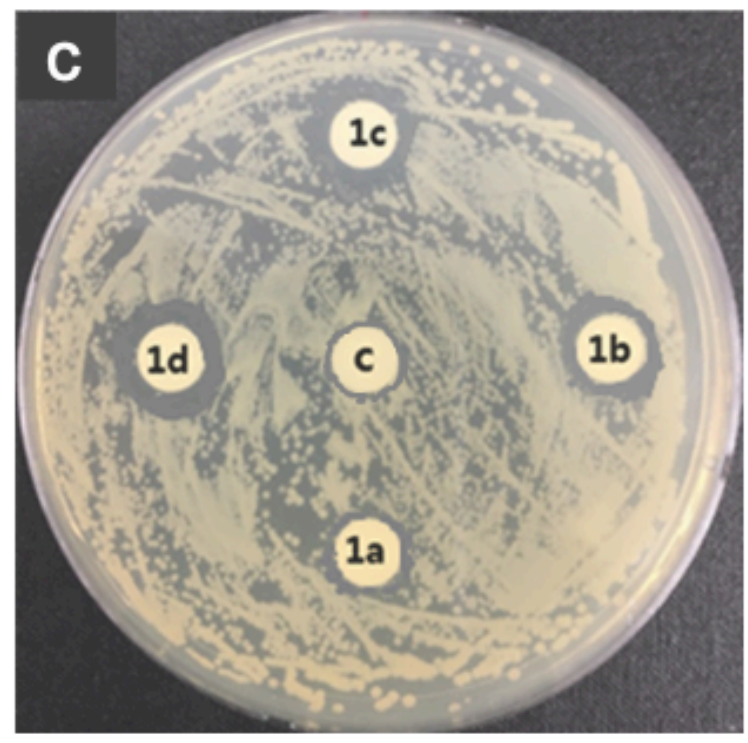

Staphylococcus aureus КCCM 29231

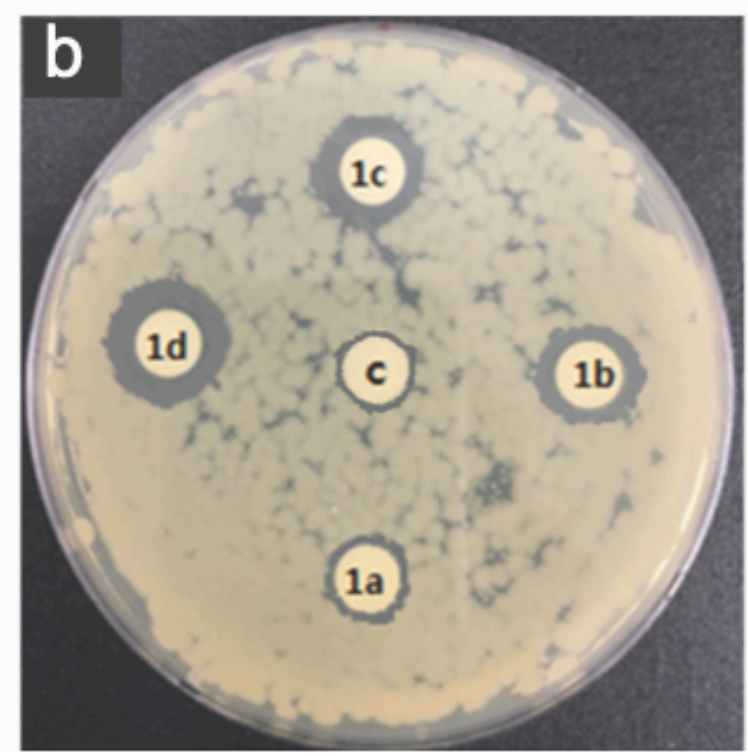

\section{Pseudomonas aeruginosa KCCM 11321}

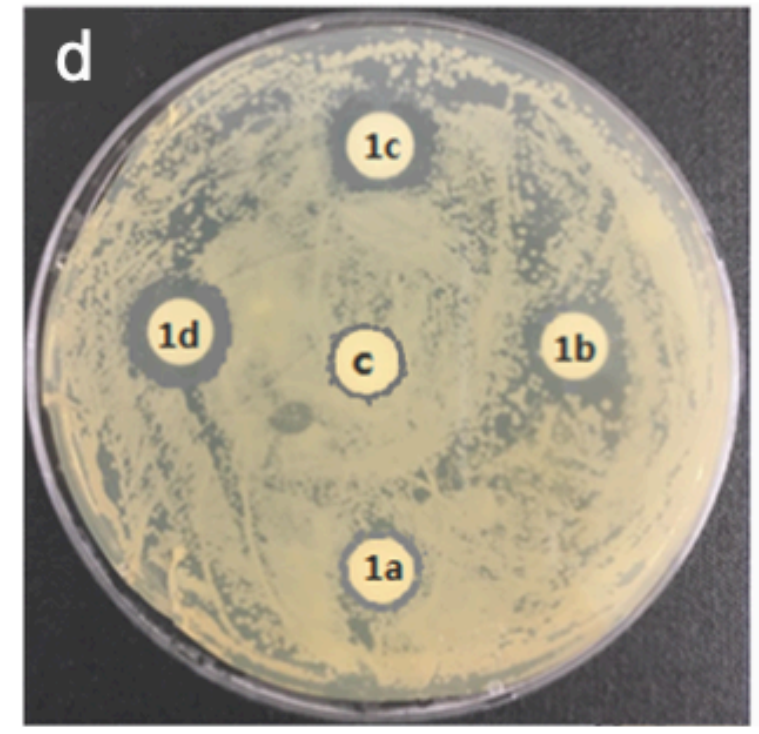

Bacillus cereus KCCM 11204

Figure S16. Antibacterial activity of the AC@AgNPs against (a, b) GN bacteria (E. coli, P. aeruginosa) and (c, d) GP bacteria ( $S$. aureus, B. cereus) at various concentrations. 


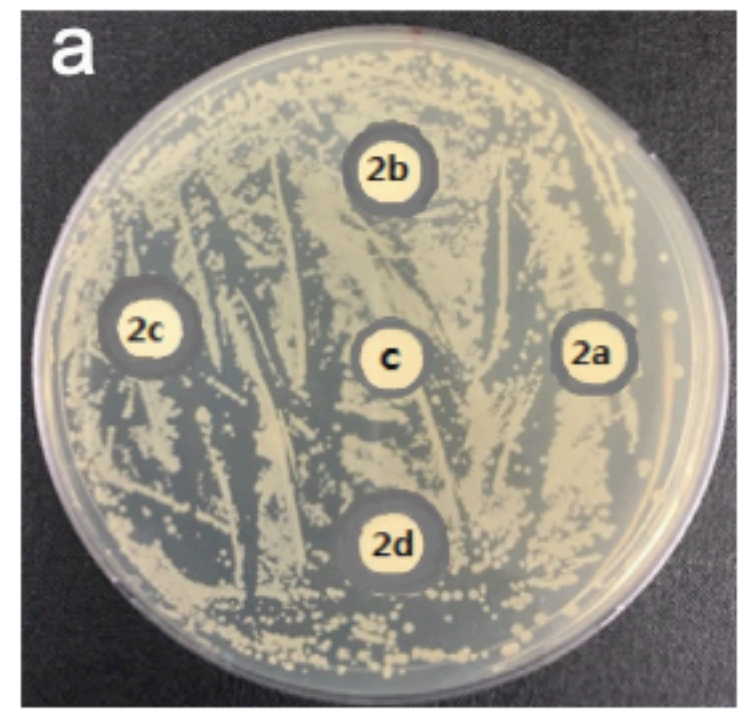

Escherichia coli KCCM 52922

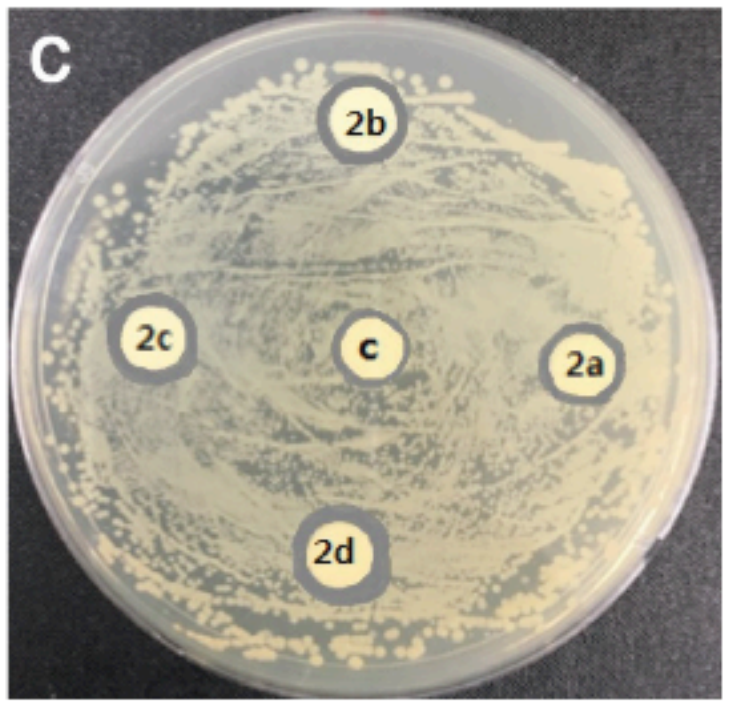

Staphylococcus aureus KCCM 29231

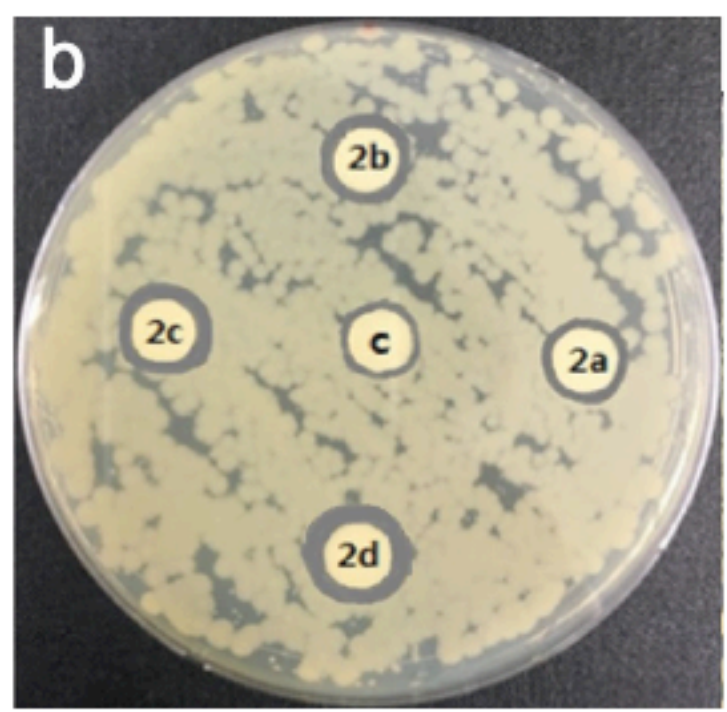

\section{Pseudomonas aeruginosa KCCM 11321}

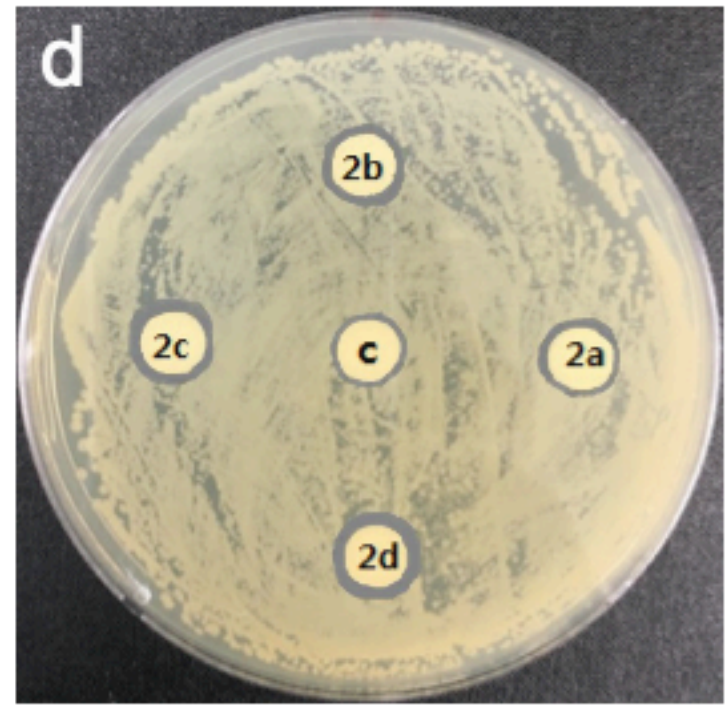

Bacillus cereus KCCM 11204

Figure S17. Antibacterial activity of the C@AgNPs against (a, b) GN bacteria (E. coli, $P$. aeruginosa) and (c, d) GP bacteria (S. aureus, B. cereus) at various concentrations. 
(a)

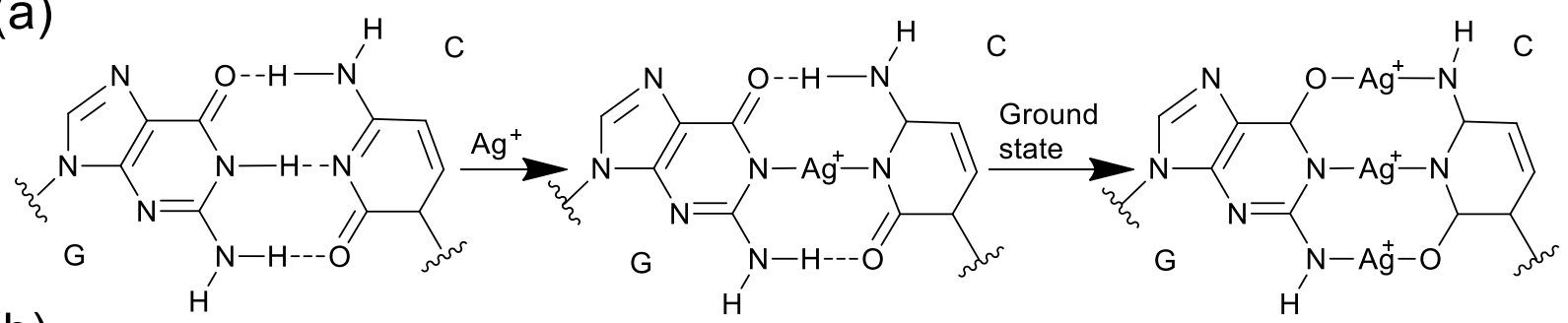

(b)

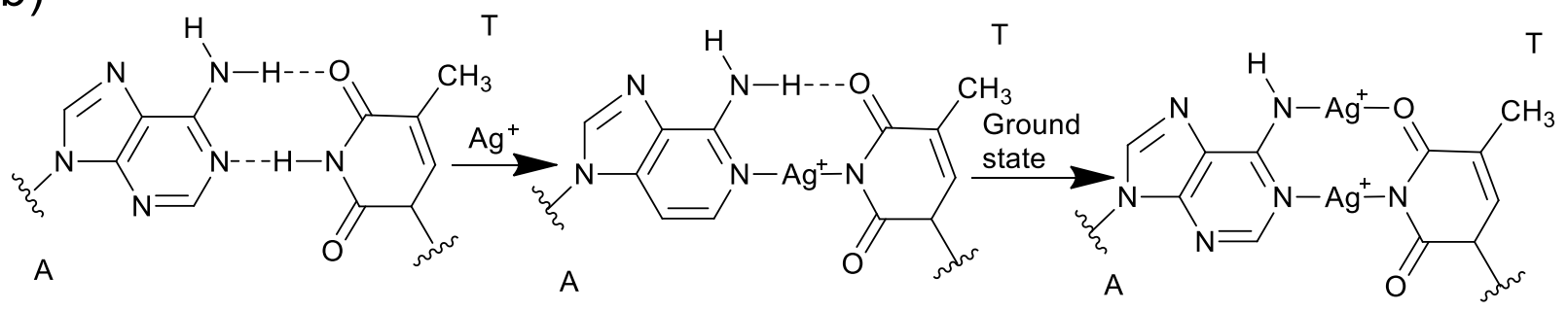

Figure S18. DNA damage owing to $\mathrm{Ag}^{+}$two-coordinated complex generation within DNA basepairs of $\mathrm{G} \equiv \mathrm{C}$ (triple hydrogen bond) and $\mathrm{A}=\mathrm{T}$ (double hydrogen bond): (a) $\mathrm{G} \equiv \mathrm{C}$ base pair, linear twofold coordinated structure, Ag complex formation in $\mathrm{G}, \mathrm{C}$ pair ground state; $\mathrm{O}-\mathrm{Ag}^{+}-\mathrm{N}, \mathrm{N}-$ $\mathrm{Ag}^{+}-\mathrm{N}, \mathrm{N}-\mathrm{Ag}^{+}-\mathrm{O}$, (b) $\mathrm{A}=\mathrm{T}$ base pair, planar linear twofold coordinated structure, $\mathrm{Ag}$ complex formation in $\mathrm{A}, \mathrm{T}$ pair ground state; $\mathrm{N}-\mathrm{Ag}^{+}-\mathrm{O}, \mathrm{N}-\mathrm{Ag}^{+}-\mathrm{N}$.

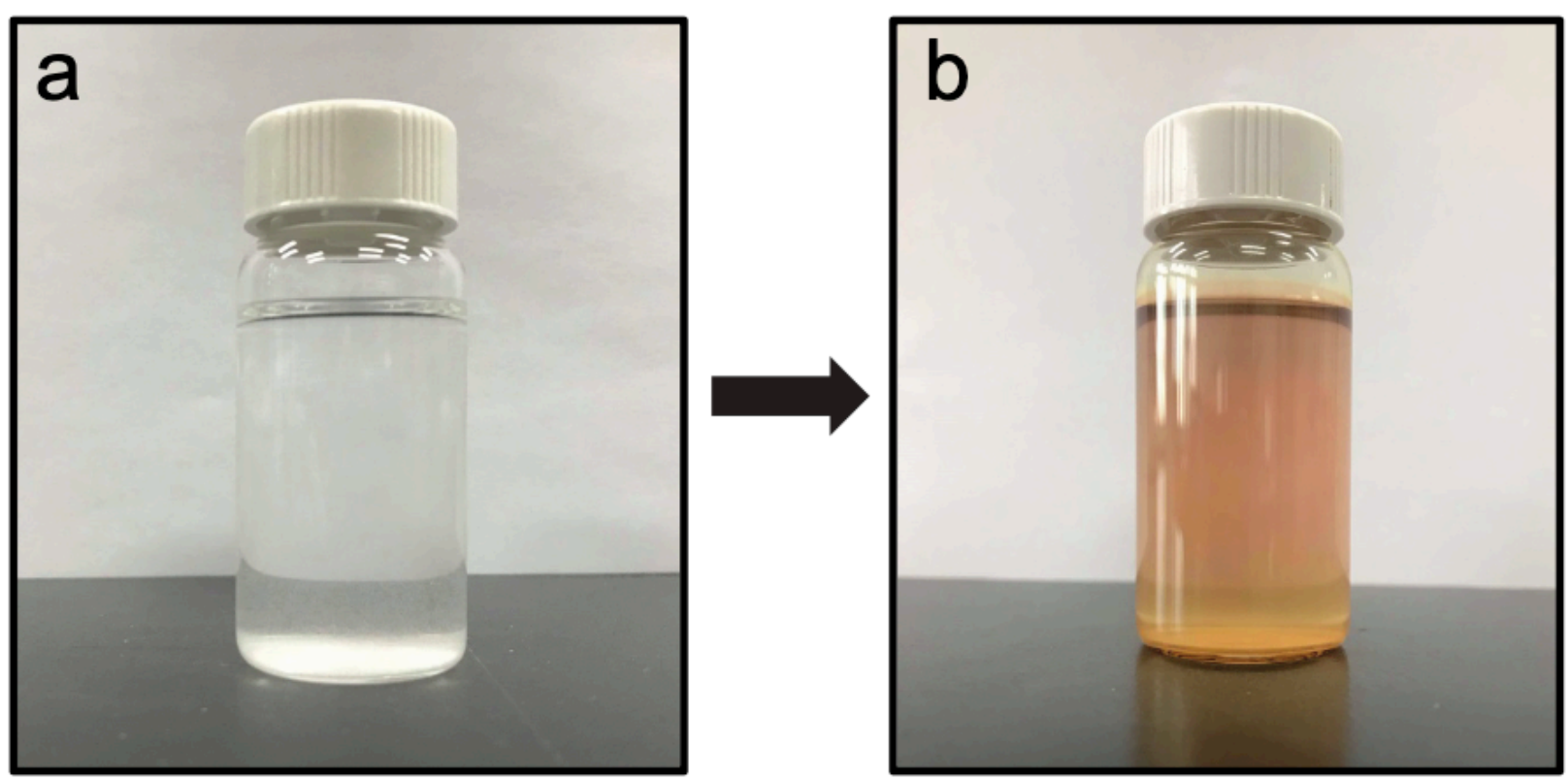

Figure S19. (a) Colorless reaction mixture before the formation of C@AgNPs. (b) After 120 min of sonication at $65^{\circ} \mathrm{C}$, the mixture turns light-brown, indicating the formation of C@AgNPs with a carbon double-layer. 
Annexin V/PI staining by flow cytometry results were compared with the values reported in previously published articles (Table S2). Thermally synthesized $\mathrm{TiO}_{2}$ nanoparticles with photothermal therapy were applied against Hela cancer cell (cell density $2.5 \times 10^{5}$, the maximum concentration of $100 \mu \mathrm{g} / \mathrm{mL}$ ), where the cytometry results demonstrated that the live cells percentage was $10.5 \%$, early apoptosis $14.4 \%$, and late apoptosis is $56.4 \%{ }^{\mathrm{R} 9}$ Biocompatible silver/gold alloy nanoparticles were used in opposition to HepG2 cancer cells (quantity $40 \mu \mathrm{g} / \mathrm{mL}$, 24 hours); the results exhibited the live cells $64.06 \%$, early apoptosis $12.12 \%$, and late apoptosis $23.78 \%{ }^{\mathrm{R} 10}$ When commercial $\mathrm{TiO}_{2}$ nanoparticles were used against $4 \mathrm{~T} 1$ cancer cells (maximum time $48 \mathrm{~h}$, cell density $1 \times 10^{6}$, maximum quantity $200 \mu \mathrm{g} / \mathrm{mL}$ ), the results show the live cells $67.7 \%$, early apoptosis $21.0 \%$, and late apoptosis $10.4 \%{ }^{\mathrm{R} 11}$ Chemically synthesized mesoporous silica nanoparticles with amino and thiol groups were prepared and covalently modified to prevent the metabolic deactivation of methotrexate and 6-mercaptopurine. These nanoparticles were driven in opposition to K562 cancer cells (cell density $1 \times 10^{6}$, concentration $30 \mu \mathrm{g} / \mathrm{mL}$ ), and the results display the live cells $71.13 \%$, early apoptosis $18.97 \%$, and late apoptosis $9.80 \%{ }^{\mathrm{R} 12} \quad \mathrm{TiO}_{2}$ nanomaterials when used as anticancer drug carriers for synergistic therapy of breast cancer cells (MCF-7, density- $1 \times 10^{4}$, concentration- $1 \times 10^{4}$ ), results displayed live cells $2.51 \%$, early apoptosis $0.02 \%$ and late apoptosis $95.9 \% .{ }^{\mathrm{R} 13}$ In contrast, we used higher density of K562 cancer cells $\left(5 \times 10^{6}\right)$ but lower concentrations of the anti-cancer agents. The quantity of $2.13 \mu \mathrm{g}$ of the as-prepared samples showed the optimum results; live cell $2.4 \%$, early apoptosis $4.7 \%$, and late apoptosis $92.8 \%$ for AC@AgNPs, whereas the same concentration of C@AgNPs showed the live cell $2.7 \%$, early apoptosis $12.9 \%$, and late apoptosis $84.2 \%$. Furthermore, Hep3b cancer cells with low concentration of the samples $(2.5 \mu \mathrm{g} / \mathrm{mL})$ were used, resulting in $86.3,91.9$, and $97,8 \%$ late apoptosis for C@AgNPs, AC@AgNPs, and AgNPs, respectively. Compared to the previously reported values in the literature, our prepared mono and double-layer carbon encapsulated silver nanoparticles showed significantly robust activity against cancer cells with carbon layer dependent toxicity control. In the cell viability test, we got the same results; C@AgNPs and AC@AgNPs showed a remarkable activity against cancer cells compared to the reported articles (Table S3) ${ }^{\text {R9- }}$ R11, R14 
Table S2. Comparison of the results of Annexin V/PI staining by flow cytometry in our work with results reported elsewhere.

\begin{tabular}{|c|c|c|c|c|c|c|c|c|}
\hline \multirow{2}{*}{ Synthesis } & \multirow{2}{*}{$\begin{array}{l}\text { Cancer } \\
\text { cell line }\end{array}$} & \multirow{2}{*}{$\begin{array}{l}\text { Cell density } \\
\text { (cells per } \\
\text { well) }\end{array}$} & \multirow{2}{*}{$\begin{array}{l}\text { Nanoparticle } \\
\text { concentration } \\
(\mu \mathrm{g} / \mathrm{mL})\end{array}$} & \multirow{2}{*}{$\begin{array}{l}\text { Time } \\
\text { (h) }\end{array}$} & \multicolumn{3}{|c|}{ Nanoparticle } & \multirow{2}{*}{$\begin{array}{l}\text { Ref. } \\
\text { No. }\end{array}$} \\
\hline & & & & & $\begin{array}{l}\text { Late apoptosis } \\
(\%)\end{array}$ & $\begin{array}{l}\text { Early apoptosis } \\
(\%)\end{array}$ & Live cells (\%) & \\
\hline $\begin{array}{l}\text { Thermal } \\
\text { synthesis }\end{array}$ & $\mathrm{HeLa}$ & $2.5 \times 10^{5}$ & 50,100 & 24 & $\begin{array}{l}\mathrm{TiO}_{2}(2.8,3.6), \\
\mathrm{TiO}_{2}+\mathrm{IR}(45.3, \\
56.4)\end{array}$ & $\begin{array}{l}\mathrm{TiO}_{2}(1.6,2.0) \\
\mathrm{TiO}_{2}+\mathrm{IR}(12.7 \\
14.4)\end{array}$ & $\begin{array}{l}\mathrm{TiO}_{2}(93.8,92.2) \\
\mathrm{TiO}_{2}+\mathrm{IR}(29.2, \\
10.5)\end{array}$ & R9 \\
\hline Biosynthesis & HepG2 & N/A & 40 & 24 & $\begin{array}{l}\text { AgNPs }(27.50), \\
\text { AuNPs }(15.10), \\
\text { Ag/AuNPs } \\
(23.78)\end{array}$ & $\begin{array}{l}\text { AgNPs (10.72), } \\
\text { AuNPs (10.50), } \\
\text { Ag/AuNPs (12.2) }\end{array}$ & $\begin{array}{l}\text { AgNPs (61.72), } \\
\text { AuNPs (73.75), } \\
\text { Ag/AuNPs } \\
(64.06)\end{array}$ & $\mathrm{R} 10$ \\
\hline Commercial & $\begin{array}{l}4 \mathrm{~T} 1 \\
\text { cells }\end{array}$ & $1 \times 10^{6}$ & $50,100,200$ & 24,48 & $\begin{array}{l}\mathrm{TiO}_{2} \mathrm{NP} 1-48 \mathrm{~h} \\
(4.11,4.87,10.4), \\
\mathrm{TiO}_{2} \mathrm{NP} 1-24 \mathrm{~h} \\
(5.95,5.92,7.42)\end{array}$ & $\begin{array}{l}\mathrm{TiO}_{2} \mathrm{NP} 1-48 \text { hours } \\
(14.4,16.9,21.0) \text {, } \\
\mathrm{TiO}_{2} \mathrm{NP} 1-24 \text { hours } \\
(9.39,8.46,5.70)\end{array}$ & $\begin{array}{l}\mathrm{TiO}_{2} \mathrm{NP} 1-48 \\
\text { hours }(80.9 \text {, } \\
77.4,67.7), \\
\mathrm{TiO}_{2} \mathrm{NP} 1-24 \mathrm{~h} \\
(84.0,84.9,85.2)\end{array}$ & R11 \\
\hline $\begin{array}{l}\text { Chemical } \\
\text { synthesis }\end{array}$ & K562 & $1 \times 10^{6}$ & 30 & 24 & $\begin{array}{l}\text { MSNSN }(5.29 \pm \\
2.81), 6-M P- \\
\text { MSNSN-MTX } \\
(9.80 \pm 2.65)\end{array}$ & $\begin{array}{l}\text { MSNSN } \\
(5.5 \pm 2.31), 6-M P- \\
\text { MSNSN-MTX } \\
(18.97 \pm 0.75)\end{array}$ & $\begin{array}{l}\text { MSNSN } \\
(89.14 \pm 5.0), 6- \\
\text { MP-MSNSN- } \\
\text { MTX }(71.13 \pm \\
3.23)\end{array}$ & $\mathrm{R} 12$ \\
\hline Solvothermal & MCF-7 & $1 \times 10^{4}$ & 150 & 24 & $\begin{array}{l}\text { NC-FA+NIR } \\
(88.7), \text { NC-FA- } \\
\text { DOX + NIR } \\
(95.9)\end{array}$ & $\begin{array}{l}\text { NC-FA+NIR } \\
(0.38), \text { NC-FA- } \\
\text { DOX + NIR }(0.02)\end{array}$ & $\begin{array}{l}\text { NC-FA+NIR } \\
(10.2), \text { NC-FA- } \\
\text { DOX + NIR } \\
(2.51)\end{array}$ & R13 \\
\hline Solvothermal & $\begin{array}{l}\text { K562, } \\
\text { Hep3B }\end{array}$ & $5 \times 10^{6}$ & $\begin{array}{l}0.71,1.42, \\
2.13 \& 2.84 \\
\text { for K562, } \\
\text { and 2.5 for } \\
\text { Hep3B }\end{array}$ & 24 & $\begin{array}{l}\text { C@AgNPs, } \\
\text { AC@AgNPs } \\
\text { (Figure } 6 \text { \& S15) }\end{array}$ & $\begin{array}{l}\text { C@AgNPs, } \\
\text { AC@AgNPs } \\
\text { (Figure } 6 \text { \& S15) }\end{array}$ & $\begin{array}{l}\text { C@AgNPs, } \\
\text { AC@AgNPs } \\
\text { (Figure } 6 \text { \& S15) }\end{array}$ & $\begin{array}{l}\text { Our } \\
\text { work }\end{array}$ \\
\hline
\end{tabular}


Table S3. Comparison of the cell viability performance of our materials with that of materials reported elsewhere.

\begin{tabular}{|c|c|c|c|c|c|c|}
\hline Synthesis & $\begin{array}{l}\text { Cancer } \\
\text { cell line }\end{array}$ & $\begin{array}{l}\text { Cell density } \\
\text { (cells per well) }\end{array}$ & $\begin{array}{l}\text { Nanoparticle } \\
\text { conc. }(\mu \mathrm{g} / \mathrm{mL})\end{array}$ & Time (h) & Cell viability (\%) & $\begin{array}{l}\text { Ref. } \\
\text { No. }\end{array}$ \\
\hline Thermal synthesis & $\mathrm{HeLa}$ & $2.5 \times 10^{5}$ & $\begin{array}{l}\mathrm{TiO} 2(10,20, \\
50,100,200), \\
\mathrm{TiO} 2+\text { photo } \\
\text { thermal } \\
\text { irradiation }(50, \\
100)\end{array}$ & $\begin{array}{l}\mathrm{TiO} 2-24 \\
\mathrm{~h}, \text { photo } \\
\text { thermal } \\
\text { irradiation } \\
5 \text { minute }\end{array}$ & $\begin{array}{l}\mathrm{TiO} 2(\sim 90), \mathrm{TiO} 2+\text { photo thermal } \\
\text { irradiation }(\sim 10)\end{array}$ & R9 \\
\hline Biosynthesis & HepG2 & $1 \times 10^{5}$ & $\begin{array}{l}\text { Ag-NPs, Au- } \\
\text { NPs, } \mathrm{Ag} / \mathrm{Au}- \\
\text { NPs }(6.25, \\
12.50,25,50 \text {, } \\
100)\end{array}$ & 24 & $\begin{array}{l}\text { Ag-NPs- } 96.51,80.88,64.51,38.76 \\
\text { 24.16 Au-NPs- } 94.09,81.94,68.94 \\
\text { 42.97, } 30.44 \text { Ag/Au-NPs- } 93.2 \\
\text { 81.76, 66.02, 39.95, } 24.94\end{array}$ & $\mathrm{R} 10$ \\
\hline Commercial & 4T1 cells & $5 \times 10^{3}$ & $\begin{array}{l}\text { Nano TiO2-NT, } \\
\text { NP1, NP2, NP3 } \\
(150,200)\end{array}$ & 24,48 & $\begin{array}{l}24 \text { hours nano TiO2- (NT, NP1, NP2, } \\
\text { NP3 }(\sim 90, \sim 70-80), 48 \text { hours nano } \\
\text { TiO2-NT, NP1, NP2, NP3 ( } \sim 70 \text { to } \\
80, \sim 50 \text { to } 80)\end{array}$ & R11 \\
\hline $\begin{array}{l}\text { Chemical } \\
\text { synthesis }\end{array}$ & $\begin{array}{l}\text { A549, } \\
\text { DU145, } \\
\text { HeLa }\end{array}$ & $1 \times 10^{6}$ & $\begin{array}{l}\text { SCS, b-AuNP, } \\
\text { c-AuNP, } \\
\text { doxorubicin } \\
\text { (specific } \\
\text { amount-2.5, 5.0, } \\
10 \mu \mathrm{g} \text { ) }\end{array}$ & 48 & $\begin{array}{l}\text { [A549 (SCS } \sim 80 \text { to } 90, \text { b-AuNP } \sim 57 \\
\text { to } 83, \text { c-AuNP } \sim 95 \text { to } 99, \\
\text { Doxorubicin } \sim 35 \text { to } 45 \text { )], [DU145 } \\
\text { (SCS } \sim 82 \text { to } 94, \text { b-AuNP } \sim 35 \text { to } 67, \\
\text { c-AuNP } \sim 95 \text { to } 99, \text { Doxorubicin } \sim \\
30 \text { to } 38 \text { )], [HeLa (SCS } \sim 82 \text { to } 90, \text { b- } \\
\text { AuNP } \sim 35 \text { to } 72, \text { c-AuNP } \sim 95 \text { to } 99 \text {, } \\
\text { Doxorubicin } \sim 30 \text { to } 34]\end{array}$ & $\mathrm{R} 14$ \\
\hline Solvothermal & K562 & $5 \times 10^{6}$ & 2.13 & $\begin{array}{l}6,12,24 \\
48\end{array}$ & $\begin{array}{l}\text { C@AgNPs }(16.5,14.5,13.26,13.0) \\
\text { AC@AgNPs }(17.76,8.5,6.7,4.8) \\
\text { (Figure 8) }\end{array}$ & $\begin{array}{l}\text { Our } \\
\text { work }\end{array}$ \\
\hline
\end{tabular}


Table S4. Antibacterial inhibition zone of AC@AgNPs against GP (KCCM 29231-S. aureus, KCCM 11204-B. cereus) and GN (KCCM 52922-E. coli, KCCM 11321-P. aeruginosa) bacteria. Data are reported as mean $\pm \mathrm{SD}$ of three measurements. Figure S16 shows the dose dependent 4 fraction with control (C-control, 1a-0.71, 1b-1.42, 1c-2.13, and 1d-2.84 $\mathrm{gg} / \mathrm{mL}$ ) of AC@AgNPs used against GP and GN bacteria.

\begin{tabular}{|c|c|c|c|c|}
\hline \multirow{2}{*}{ Sample $(\mu \mathrm{g} / \mathrm{mL})$} & \multicolumn{4}{|c|}{ Inhibition zone (diameter in $\mathrm{mm}$ ) } \\
\hline & S. aureus & B. cereus & E. coli & P. aeruginosa \\
\hline $\mathrm{C}_{2} \mathrm{H}_{3} \mathrm{AgO}_{2}(1.11)^{\mathrm{c}}$ & $8.71 \pm 0.35$ & $8.68 \pm 0.23$ & $8.98 \pm 0.23$ & $8.80 \pm 0.27$ \\
\hline AC@AgNPs $(0.71)^{1 \mathrm{a}}$ & $10.50 \pm 0.58$ & $10.37 \pm 0.48$ & $11.92 \pm 0.48$ & $10.87 \pm 0.48$ \\
\hline AC@AgNPs $(1.42)^{1 b}$ & $13.25 \pm 0.42$ & $13.00 \pm 0.12$ & $16.32 \pm 0.26$ & $14.00 \pm 0.41$ \\
\hline $\operatorname{AC@} @ \operatorname{AgNPs}(2.13)^{1 \mathrm{c}}$ & $15.37 \pm 0.42$ & $14.50 \pm 0.58$ & $19.00 \pm 0.90$ & $15.80 \pm 0.19$ \\
\hline $\operatorname{AC} @ \operatorname{AgNPs}(2.84)^{1 \mathrm{~d}}$ & $17.25 \pm 0.43$ & $16.37 \pm 0.25$ & $22.00 \pm 0.41$ & $18.25 \pm 0.22$ \\
\hline
\end{tabular}

Table S5. Antibacterial inhibition zone of C@AgNPs against GP (KCCM 29231-S. aureus, KCCM 11204-B. cereus) and GN (KCCM 52922-E. coli, KCCM 11321-P. aeruginosa) bacteria. Data are reported as mean \pm SD of three measurements. Figure S17 shows the dose dependent 4 fraction with control (C-control, 2a-0.71, 2b-1.42, 2c-2.13, and 2d-2.84 $\mu \mathrm{g} / \mathrm{mL}$ ) of C@AgNPs used against GP and GN bacteria.

\begin{tabular}{ccccc}
\hline \hline & \multicolumn{4}{c}{ Inhibition zone (diameter in mm) } \\
\cline { 2 - 5 } Sample $(\mu \mathrm{g} / \mathrm{mL})$ & S. aureus & B. cereus & E. coli & P. aeruginosa \\
\hline $\mathrm{C}_{2} \mathrm{H}_{3} \mathrm{AgO}_{2}(1.11)^{\mathrm{c}}$ & $8.60 \pm 0.132$ & $8.56 \pm 0.231$ & $8.94 \pm 0.213$ & $8.75 \pm 0.332$ \\
$\mathrm{C} @ A g N P s(0.71)^{2 \mathrm{a}}$ & $10.34 \pm 0.577$ & $10.12 \pm 0.478$ & $11.00 \pm 0.345$ & $10.65 \pm 0.478$ \\
$\mathrm{C} @ \operatorname{AgNPs}(1.42)^{2 \mathrm{~b}}$ & $12.75 \pm 0.265$ & $12.62 \pm 0.105$ & $13.62 \pm 0.342$ & $13.30 \pm 0.332$ \\
$\mathrm{C} @ \operatorname{AgNPs}(2.13)^{2 \mathrm{c}}$ & $14.33 \pm 0.424$ & $14.10 \pm 0.577$ & $15.04 \pm 0.567$ & $14.70 \pm 0.243$ \\
$\mathrm{C} @ \operatorname{AgNPs}(2.84)^{2 \mathrm{~d}}$ & $15.45 \pm 0.332$ & $15.21 \pm 0.132$ & $17.10 \pm 0.378$ & $15.87 \pm 0.216$ \\
\hline \hline
\end{tabular}


Table S6 shows the comparative results of our products with AgNPs based composites available in the literature. Biosynthesis of silver nanoparticles, ${ }^{\mathrm{R} 15}$ and AgNPs colloids synthezed in imidazolium halide ionic liquid, ${ }^{\mathrm{R} 16}$ both cases used 100 and $250 \mu \mathrm{g} / \mathrm{mL}$ (particle concentration) and $1 \times 10^{7}$ and $1 \times 10^{8}$ colonies forming units (CFU) of bacteria, but the results displayed the moderate inhibition zones. Similar results were obtained with chemically synthesized lignin/silica AgNPs, ${ }^{\text {R17 }}$ where a huge amount of composite nanoparticles $(15000 \mu \mathrm{g} / \mathrm{mL})$ and bacteria density $\left(1 \times 10^{6}\right)$ were used. Although there was the use of larger quantities of nanoparticles, the zone of inhibition was low. In our case, low concentration of nanoparticles and higher bacterial density $\left(1.5 \times 10^{8}\right)$ showed the noteworthy inhibition zones. Bacteria threshold depends on bacterial concentration. To destroy high density of bacteria, a higher amount of effective nanoparticles is needed. A large amount of bacteria means high-density colonies, which is not easy to trap by the nanoparticles. Generally, high-density bacterial areas do not show threshold problems, but lowdensity areas make the threshold problem due to insufficient bacteria. In low bacterial density, it is easy to make large inhibition zone by the nanoparticles. Since we used higher bacterial density $\left(1.5 \times 10^{8}\right)$, it is tough to make a large inhibition zone. Nevertheless, we might have prepared highly dispersed small-sized carbon-coated AgNPs, which increased the toxic percentage by the $\mathrm{Ag}^{+}$ions releasing system. From the discussion above, we can conclude that AC@AgNPs are more effective bactericidal agents due to the monolayer carbon's faster $\mathrm{Ag}^{+}$release compared to C@AgNPs. 
Table S6. Comparison of antibacterial performance of our work with that of other AgNPs based nanoparticles.

\begin{tabular}{|c|c|c|c|c|c|c|c|c|}
\hline $\begin{array}{l}\text { Synthesis } \\
\text { process }\end{array}$ & Nanomaterial & $\begin{array}{l}\text { Particle } \\
\text { shape }\end{array}$ & $\begin{array}{l}\text { Particle } \\
\text { size } \\
(\mathrm{nm})\end{array}$ & $\begin{array}{l}\text { Particle } \\
\text { Conc. } \\
(\mu \mathrm{g} / \mathrm{mL})\end{array}$ & $\begin{array}{l}\text { Bact. } \\
\text { conc. } \\
\text { (cfu/mL) }\end{array}$ & $\begin{array}{l}\text { Bact. Inhibition } \\
\text { zone }(\mathrm{mm})\end{array}$ & $\begin{array}{l}\text { Reference drug or } \\
\text { control Inhibition zone } \\
(\mathrm{mm})\end{array}$ & $\begin{array}{l}\text { Ref. } \\
\text { No. }\end{array}$ \\
\hline $\begin{array}{l}\text { Bio } \\
\text { synthesis }\end{array}$ & Silver nanoparticle & Spherical & $\begin{array}{l}\text { average } \\
\text { particle } \\
\text { size } 45\end{array}$ & 100 & $1 \times 10^{7}$ & $\begin{array}{l}\text { E. coli }(13.72 \pm 0.6) \\
\& S . \text { aureus } \\
(9.53 \pm 0.6)\end{array}$ & N/A & $\mathrm{R} 15$ \\
\hline $\begin{array}{l}\text { Ionic } \\
\text { liquids } \\
\text { way }\end{array}$ & $\begin{array}{l}\text { AgNPs colloids in } \\
\text { four imidazolium } \\
\text { halide } \\
\mathrm{Ag}-\left[\mathrm{C}_{4} \mathrm{MIM}\right][\mathrm{Cl}] \\
\mathrm{Ag}-\left[\mathrm{C}_{4} \mathrm{MIM}\right][\mathrm{Br}] \\
\mathrm{Ag}-\left[\mathrm{C}_{4} \mathrm{MIM}\right][\mathrm{I}] \\
\mathrm{Ag}-[\mathrm{C} 4 \mathrm{MIM}]\left[\mathrm{BF}_{4}\right]\end{array}$ & $\begin{array}{l}\text { Spherical } \\
\text { for }[\mathrm{Cl}] \\
{[\mathrm{Br}],[\mathrm{I}]} \\
\text { and rod } \\
\text { for } \mathrm{BF}_{4}\end{array}$ & $\begin{array}{l}{[\mathrm{Cl}]-6,} \\
{[\mathrm{Br}]-4,} \\
{[\mathrm{I}]-2,} \\
{\left[\mathrm{BF}_{4}\right]-} \\
13\end{array}$ & 250 & $1 \times 10^{8}$ & $\begin{array}{l}\text { B. cereus- }[\mathrm{Cl}]-11 \\
( \pm 1.4),[\mathrm{Br}]-13 \\
( \pm 1.1),[\mathrm{I}]-24 \\
( \pm 1.5), \mathrm{Ag}-\left[\mathrm{BF}_{4}\right]- \\
15( \pm 0.9), \text { E. coli- } \\
{[\mathrm{Cl}] 8( \pm 1.2),[\mathrm{Br}]} \\
10( \pm 1.1),[\mathrm{I}]-21 \\
( \pm 1.6),\left[\mathrm{BF}_{4}\right]-14 \\
( \pm 1.3)\end{array}$ & $\begin{array}{l}\text { Ciprofloxacin- } \\
\text { B. cereus } 3( \pm 1.2) \\
\text { E. coli-2 }( \pm 0.5)\end{array}$ & $\mathrm{R} 16$ \\
\hline $\begin{array}{l}\text { Chemical } \\
\text { synthesis }\end{array}$ & $\begin{array}{l}\text { lignin/silica AgNPs } \\
\text { Silica Syloid } 244+ \\
20 \mathrm{w} / \mathrm{w} \text { of lignin } \\
+\mathrm{AgNPs}\end{array}$ & irregular & $\begin{array}{l}\text { Size } \\
\text { range } \\
(30-36)\end{array}$ & 15000 & $1 \times 10^{6}$ & $\begin{array}{l}\text { B. subtilis-10.67 } \\
( \pm 0.58), S . \text { aureus- } \\
11.67( \pm 0.58), P . \\
\text { aeruginosa- } 12.33 \\
( \pm 0.58), \text { E. coli- } \\
12.33( \pm 0.58), \text { K. } \\
\text { pneumoniae- } 0\end{array}$ & $\begin{array}{l}\text { Tetracycline }(30 \mu \mathrm{g}) \\
\\
\text { B. subtilis- } 28.67 \\
( \pm 0.58), \text { S. aureus- } \\
28.67( \pm 0.58), P . \\
\text { aeruginosa- } 11.00 \\
( \pm 1.00), \text { E. coli- } 26.33 \\
( \pm 0.58), \text { K. } \\
\text { pneumoniae- } 26.00 \\
( \pm 1.00)\end{array}$ & $\mathrm{R} 17$ \\
\hline $\begin{array}{l}\text { Solvo- } \\
\text { thermal }\end{array}$ & $\begin{array}{l}\text { (AC@AgNPs) \& } \\
\text { (C@AgNPs) }\end{array}$ & $\begin{array}{l}\text { Ovoid- } \\
\text { spherical }\end{array}$ & $\begin{array}{l}\text { Size } \\
\text { range } \\
(4-18)\end{array}$ & $\begin{array}{l}0.71 \\
1.42 \\
2.13 \& \\
2.84\end{array}$ & $1.5 \times 10^{8}$ & $\begin{array}{l}\text { E. coli, } P \text {. } \\
\text { aeruginosa } S . \\
\text { Aureus \& B.cereus } \\
\text { inhibition zone } \\
\text { (Tables S3 \& S4) }\end{array}$ & $\begin{array}{l}\text { Silver Acetate, } \\
\text { Inhibition zone } \\
\text { (Tables S3 \& S4) }\end{array}$ & $\begin{array}{l}\text { Our } \\
\text { work }\end{array}$ \\
\hline
\end{tabular}




\section{Cell killing mechanism}

There are two key pathways by which metal nanoparticles destroy cells: touch killing and ion-mediated killing. ${ }^{\mathrm{R} 18}$ In general, the leakage of $\mathrm{Ag}^{+}$from carbon-coated AgNPs was very limited. Thus, we partially depleted the carbon layer through acidic functionalization and transformed the C@AgNPs into AC@AgNPs, whose action relies on its ability to trap bacterial cells and release $\mathrm{Ag}^{+}$. The literature contains reports of the similar action of carbon-coated nanoparticles. $^{\text {R2 }}$ The monolayer carbon of the AC@AgNPs enables a high release efficiency of $\mathrm{Ag}^{+}$ions. The escape of $\mathrm{Ag}^{+}$ions out of the AgNP surfaces disturbs the metabolic pathways and impairs the reproduction process of cancer cells and bacteria, eventually causing their death. The oxygen-containing carboxylic or carbonyl groups of the AC@AgNPs increase their affinity toward cells and form reactive oxygen species (ROS). By contrast, the C@AgNPs comprise AgNPs coated with a double-layer of carbon, which makes $\mathrm{Ag}^{+}$dissolution into the solution more difficult because of the obstruction by the carbon walls, thereby reducing the $\mathrm{Ag}^{+}$-ion emanation rate.

In general, the ion release efficiency of nanoparticles depends on thickness of surfacecovering layer. $\mathrm{Ag}^{+}$ions do not easily diffuse from the AgNPs through thicker carbon layers. Other authors used acidification to reduce the thickness of a graphite layer, which enabled the faster release of $\mathrm{Ag}^{+}$ions, which in turn enhanced cell death. ${ }^{\mathrm{R} 2} \mathrm{In}$ our case, carbon double-layers of $\mathrm{C} @ \mathrm{AgNPs}$ led to the slower release of $\mathrm{Ag}^{+}$ions and moderate activity against cancer cells and human pathogens. However, the acidified monolayer carbon-coated AC@AgNPs exhibited substantial activity. The $\mathrm{Ag}^{+}$-ions release rate was not only dependent on the carbon layer but also on the surface coarseness and specific surface area. Surface coarseness and surface area strongly influence the $\mathrm{Ag}^{+}$-ion concentration. The action of acid erodes the carbon surface and makes it much irregular. The increment in the surface coarseness of the AC@AgNPs gives rise to (i) an augmentation in the specific surface area and (ii) the insertion of oxygen-containing functional groups (carboxyl and carbonyl) on the surface (as confirmed by XPS and FT-IR measurements). The release of $\mathrm{Ag}^{+}$ions from the AC@AgNPs is dramatically increased because of the rougher surface of the carbon layer. Also, the rougher surface may foster the retention of microbes on the surface. A large surface area results in greater toxicity because of the broad area of interaction with cells. The surface-modified AC@AgNPs have a large specific surface area and numerous contact sites for increased cell adsorption. In addition, their carboxyl and carbonyl groups would increase the cell affinity and eventually kill cancer cells and bacteria.

We observed a larger inhibition zone against GN bacterial strains than against GP strains. The electrostatic attraction between the cell wall with negative charge and the $\mathrm{Ag}^{+}$ions with positive charge is the key to the $\mathrm{Ag}^{+}$ions' bactericidal activity. An increase in the contact area between the exposed surface and the cell wall due to the coarse surface of NPs can improve the adhesion of GN bacteria but not the adhesion of GP bacteria because GP bacteria do not bear an additional outer membrane that promotes their attachment to rough surfaces. ${ }^{\mathrm{R} 19}$ The GP and GN bacterial cell walls exhibit some structural differences. The GN bacteria are covered by a thin layer with a negatively charged exterior lipopolysaccharide layer (7-8 nm width). However, the GP cell 
walls comprise of a dense and strongly cross-linked layer of rigid peptidoglycans (20-80 nm thickness). The greater protection offered by the GP cell wall will inhibit or avert the influence of bactericides. ${ }^{\text {R20 }}$

We prepared carbon-encapsulated thick- and thin-layered small-sized AgNPs. The small particles have a large specific surface area to adsorb nanoscale microorganisms such as bacteria. The $\mathrm{Ag}^{+}$ions interact with thiol group-containing protein units of bacterial membranes and obstruct their functions. In addition, AgNPs can be bound to the cell membrane and release $\mathrm{Ag}^{+}$ ions, which can react with mitochondrial respiratory chains, leading to cell destruction. ${ }^{\mathrm{R} 21} \mathrm{AgNPs}$ may release $\mathrm{Ag}^{+}$ions in an acid solution inside the cells. It creates reactive radicals and induces oxidative pressure. This effect will improve the performance of bactericides. 


\section{HR-TEM measurement}

Focusing of the the electron beam of TEM is an important issue to coprrectly prove the thin carbon layer structure. It is also about a well-known potential dispute in many scientific TEM results. In the hope of resolving the issue, we have repeatedly carried out our experiments carefully, each time, obtaining the same result. We provided HR-TEM images (Figures 4 and 5) to prove the existence of double layer carbon and mono layer carbon on the surface of AgNPs. In fact, we employed this technique based on the literature. Many publications have proved the carbon coating of their products via HR-TEM microscopy. ${ }^{\text {R22-R27 }}$ All TEM publications may have this kind of issue in their image, but we believe that they have published the best reliable images.

Furthermore, when the TEM beam was not focused correctly, the images of the particles were not clear, particle lattice spacing could not be observed clearly, and the crystal structure could not be observed clearly resulting amorphous phase like structures. We ensured perfect focusing of the TEM electron beam, such that it could show the carbon double layer as well as lattice spacing, crystal structure, and clear particle shapes (Figures 4, 5, and S3). The main point, if the electron beam was not correctly focused, the lattice spacing was never observed clearly. In addition, if the low-resolution TEM images show the mono or double layer due to incorrect electron beam, the high resolution image never shows the mono or double layers for incorrect electron beam as the incorrect electron beam makes the image blurred.

\section{References}

(R1) Afanasov, I. M.; O.N.; Shornikova, Kirilenko, D. A.; Vlasov, I. I.; Zhang, L.; Verbeeck, J.; Avdeev, V.V.; Tendeloo, G. V. Graphite structural transformations during intercalation by $\mathrm{HNO}_{3}$ and exfoliation, Carbon 2010, 48, $1858-1865$.

(R2) Wang, Z.; Wang, T.; Hua, A.; Ma, S.; Zhang, Z.; Liu, L. Prolonged Antimicrobial Activity of Silver Core-Carbon Shell Nanoparticles. Korean J. Chem. Eng. 2019, 36, 1882-1889.

(R3) Toebes, M. L.; Heeswijk, J. M. P.; Bitter, J. H.; Dillen, A. J.; Krijn, P. J. The influence of oxidation on the texture and the number of oxygen-containing surface groups of carbon nanofibers. Carbon 2004, 42, 307-315.

(R4) Hahn, J. R. Kinetic study of graphite oxidation along two lattice directions. Carbon 2005, 43, 1506-1511.

(R5) Hahn, J. R.; Kang, H. Local and non-local functions of Cs promoter in the O2-oxidation of graphite. J. Phys. Chem. B 2002, 106, 7445-7448.

(R6) Hahn, J. R.; Kang, H.; Lee, S. M.; Lee, Y. H. Mechanistic study of defect induced oxidation of graphite. J. Phys. Chem. B 1999, 103, 9544-9551. 
(R7) Hahn, J. R. Promoted graphite oxidation in the presence of Cs trapped between basal planes. Surf. Sci. 1999, 423, L216-L221.

(R8) Lee, S. M.; Lee, Y. H.; Hwang, Y. G.; Hahn, J. R.; Kang, H. Defect-induced oxidation of graphite. Phys. Rev. Lett. 1999, 82, 217-220.

(R9) Lei, S.; Zhenglin, L.; Zhuo, L.; Ying, H.; Chong, C.; Chenhui, Y.; Baosheng, D.; Sun, Y.; Flemming, B.; Miao, Y. Design and Mechanism of Core-Shell $\mathrm{TiO}_{2}$ Nanoparticles as a High-Performance Photothermal Agent. Nanoscale 2017, 9, 16183.

(R10) Shanmugasundaram, T.; Radhakrishnan, M.; Gopikrishnan, V.; Kadirvelu, K.; Balagurunathan, R. Biocompatible Silver, Gold and Silver/Gold Alloy Nanoparticles for Enhanced Cancer Therapy: In Vitro and In Vivo Perspectives. Nanoscale 2017, 9, 16773.

(R11) Wang, Y.; Yao, C.; Chenchen, L.; Ding, L.; Liu, J.; Dong, P.; Fang, H.; Lei, Z.; Shi, G.; Wu, M. Excess Titanium Dioxide Nanoparticles on the Cell Surface Induce Cytotoxicity by Hindering Ion Exchange and Disrupting Exocytosis Processes. Nanoscale 2015, 7, 13105.

(R12) Wang, W.; Fang, C.; Wang, X.; Chen, Y.; Wang, Y.; Feng, W.; Yan, C.; Zhao, M.; Peng, S. Modifying Mesoporous Silica Nanoparticles to Avoid the Metabolic Deactivation of 6Mercaptopurine and Methotrexate in Combinatorial Chemotherapy. Nanoscale 2013, 5, 6249.

(R13) Ren, W.; Iqbal, M. Z.; Zeng, L.; Chen, T.; Pan, Y.; Zhao, J.; Yin, H.; Zhang, J.; Zhang, L.; Lid, A.; Wu, A. Black $\mathrm{TiO}_{2}$ Based Core-Shell Nanocomposites as Doxorubicin Carriers for Thermal Imaging Guided Synergistic Therapy of Breast Cancer. Nanoscale 2017, 9, 11195.

(R14) Kumar, C. G.; Poornachandraa, Y.; Chandrasekhar, C. Green Synthesis of Bacterial Mediated Anti-Proliferative Gold Nanoparticles: Inducing Mitotic Arrest (G2/M phase) and Apoptosis (intrinsic pathway). Nanoscale 2015, 7, 18738.

(R15) Rajoka, M. S. R; Mehwish, H. M.; Zhang, H.; Ashraf, M.; Fang, H.; Zeng, X.; Wu, Y.; Khurshid, M.; Zhao, L.; He, Z. Antibacterial and Antioxidant Activity of Exopolysaccharide Mediated Silver Nanoparticle Synthesized by Lactobacillus Brevis Isolated from Chinese Koumiss. Colloids Surf. B 2020, 186, 110734.

(R16) Patil, V.; Mahajan, S.; Kulkarni, M.; Patil, K.; Rode, C.; Coronas, A.; Yi, G. R. Synthesis of Silver Nanoparticles Colloids in Imidazolium Halide Ionic Liquids and Their Antibacterial Activities for Gram-Positive and Gram-Negative Bacteria. Chemosphere 2020, 243, 125302.

(R17) Klapiszewski, Ł.; Rzemieniecki, T.; Krawczyk, M.; Malina, D.; Norman, M.; Zdarta, J.; Majchrzak, I.; Dobrowolska, A.; Czaczyk, K.; Jesionowski, T. Kraft Lignin/Silica-AgNPs as a Functional Material with Antibacterial Activity. Colloids Surf. B 2015, 134, 220-228. 
(R18) Qasim, M.; Udomluck, N.; Chang, J.; Park, H.; Kim, K. Antimicrobial Activity of Silver Nanoparticles Encapsulated in Poly-N-isopropylacrylamide-based Polymeric Nanoparticles. Int. J. Nanomedicine 2018, 3, 235-249.

(R19) Bagherifard, S.; Hickey, D. J.; Luca, A. C.; Malheiro, V. N.; Markaki, A. E.; Guagliano, M.; Webster, T. J. The Influence of Nanostructured Features on Bacterial Adhesion and Bone Cell Functions on Severely Shot Peened 316L Stainless Steel. Biomaterials 2015, 73, 185197.

(R20) Li, K.; Zhang, Y. Y.; Jiang, G. Y.; Hou, Y. J.; Zhang, B. W.; Zhou, Q. X.; Wang, X. S. A Bivalent Cationic Dye Enabling Selective Photo-Inactivation Against Gram-Negative Bacteria. Chem. Commun. 2015, 51, 7923.

(R21) Munir, M. U.; Ahmed, A.; Usman, M.; Salman, S. Recent Advances in NanotechnologyAided Materials in Combating Microbial Resistance and Functioning as Antibiotics Substitutes. Int. J. Nanomedicine 2020, 15, 7329-7358.

(R22) Wang, Z.; Wang, T.; Hua, A.; Ma, S.; Zhang, Z.; Liu, L. Prolonged Antimicrobial Activity of Silver Core-Carbon Shell Nanoparticles. Korean J. Chem. Eng. 2019, 36, 1882-1889.

(R23) Melero, C.; Rincón, R.; Muñoz, J.; Zhang, G.; Sun, S.; Perez, A.; Royuela, O.; GonzálezGago, C.; Calzada, M. D. Scalable graphene production from ethanol decomposition by microwave argon plasma torch. Plasma Phys. Control. Fusion 2017, 60, 014009.

(R24) Xiang, L.; Junhao, L.; Qingsheng, G.; Xiang, Y.; Renzong, H.; Jun, L.; Lichun, Y.; Min, Z. MoS2 Nanosheets with Conformal Carbon Coating as Stable Anode Materials for Sodium-Ion Batteries. Electrochim. Acta 2017, 254, 172-180.

(R25) Chunnian He, Shan Wu, Naiqin Zhao, Chunsheng Shi, Enzuo Liu, Jiajun Li. CarbonEncapsulated Fe3O4 Nanoparticles as a High-Rate Lithium Ion Battery Anode Material, ACS Nano 2013, 7, 4459-4469.

(R26) Zhang, Z.; Zhao, H.; Du, Z.; Chang, X.; Zhao, L.; Du, X.; Li, Z.; Teng, Y.; Fang, J.; Świerczek, K. (101) Plane-Oriented SnS2 Nanoplates with Carbon Coating: A High-Rate and Cycle-Stable Anode Material for Lithium Ion Batteries. ACS Appl. Mater. Interfaces 2017, 9, $35880-35887$.

(R27) Jiang, B.; Tang, Y.; Qu, Y.; Wang, J. Q.; Xie. Y.; Tian, C.; Zhou, W.; Fu, H .Thin carbon layer coated $\mathrm{Ti} 3+-\mathrm{TiO} 2$ nanocrystallites for visible-light driven photocatalysis. Nanoscale 2015, 7, 5035 . 